JULIANA JARRA

Isolamento, quantificação e caracterização morfológica de células mesenquimais de sangue do cordão umbilical canino

São Paulo 


\section{Isolamento, quantificação e caracterização morfológica de células mesenquimais de sangue de cordão umbilical canino}

Dissertação apresentada ao Programa de PósGraduação em Anatomia dos Animais Domésticos e Silvestres da Faculdade de Medicina Veterinária e Zootecnia da Universidade de São Paulo para obtenção do título de Mestre em Ciências.

Departamento:

Cirurgia

Área de Concentração:

Anatomia dos Animais Domésticos e Silvestres

Orientadora:

Prof. Dra. Maria Angélica Miglino 
Autorizo a reprodução parcial ou total desta obra, para fins acadêmicos, desde que citada a fonte.

DADOS INTERNACIONAIS DE CATALOGAÇÃO-NA-PUBLICAÇÃO

(Biblioteca Virginie Buff D’Ápice da Faculdade de Medicina Veterinária e Zootecnia da Universidade de São Paulo)

Jarra, Juliana

FMVZ Isolamento, quantificação e caracterização morfológica de células mesenquimais de sangue de cordão umbilical canino / Juliana Jarra Ozório. São Paulo: J. J. Ozório, 2008.

$74 \mathrm{f}$. : il.

Dissertação (mestrado) - Universidade de São Paulo. Faculdade de Medicina Veterinária e Zootecnia. Departamento de Cirurgia, 2008.

Programa de Pós-Graduação: Anatomia dos Animais Domésticos e Silvestres.

Área de concentração: Anatomia dos Animais Domésticos e Silvestres.

Orientador: Profa. Dra. Maria Angélica Miglino.

1. Células-tronco. 2. Células mesenquimais. 3. Sangue. 4. Cordão umbilical. 5. Canino. I. Título. 


\section{FACULDADE DE MEDICINA VETERINÁRIA E ZOOTECNIA}

\section{CERTIFICADO}

Certificamos que o Projeto intitulado "Isolamento, quantificação e caracterização morfológica de células mesenquimais de sangue do cordão umbilical canino", protocolado sob o $\mathrm{n}^{\circ} 1044 / 2007$, utilizando 30 (trinta) cães, sob a responsabilidade da Profa. Dra. Maria Angélica Miglino, está de acordo com os princípios éticos de experimentação animal da Comissão de Bioética da Faculdade de Medicina Veterinária e Zootecnia da Universidade de São Paulo e foi aprovado “ad referendum".

(We certify that the Research "Isolation, quantification and characterization mesenchymal cells of canine umbilical cord blood", protocol number 1044/2007, utilizing 30 (thirty) dogs, under the responsibility Profa. Dra. Maria Angélica Miglino, agree with Ethical Principles in Animal Research adopted by Bioethic Commission of the School of Veterinary Medicine and Zootechny of University of São Paulo and was approved "ad referendum", meeting).

São Paulo, 21 de fevereiro de 2008

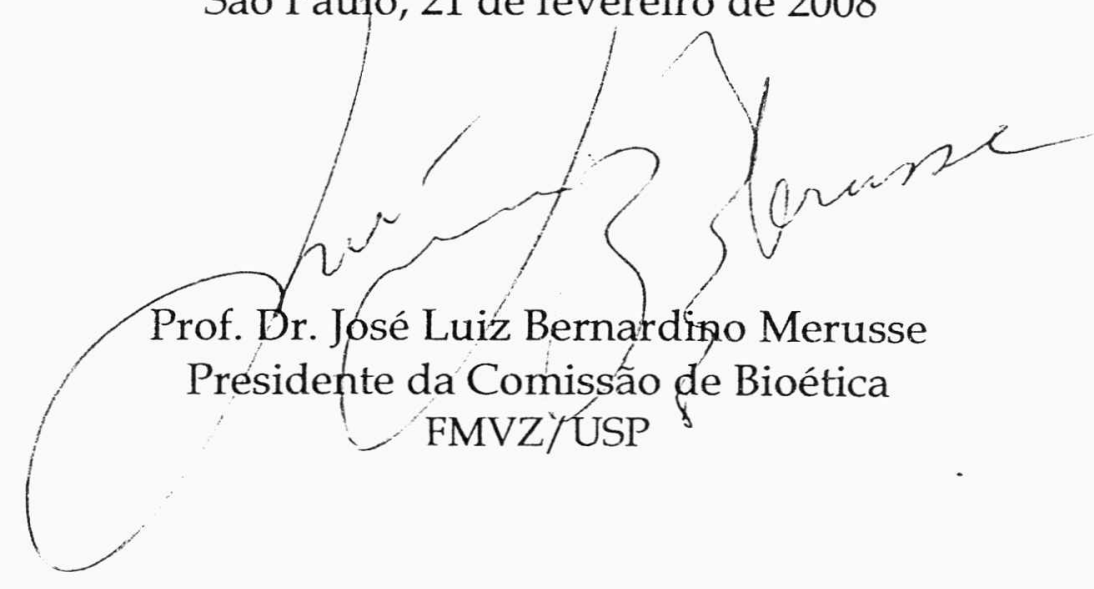


Nome: JARRA, Juliana

Título: Isolamento, quantificação e caracterização morfológica de células mesenquimais de sangue de cordão umbilical canino.

Dissertação apresentada ao Programa de Pós-Graduação em Anatomia dos Animais Domésticos e Silvestres Faculdade de Medicina Veterinária e Zootecnia da Universidade de São Paulo para a obtenção do título de Mestre em Ciências

Data: '

Banca Examinadora

Prof: Dr. Instituição:

Julgamento:

Assinatura:

Prof: Dr. Instituição:

Julgamento:

Assinatura:

Prof: Dr. Instituição:

Julgamento:

Assinatura: 


\section{Epígrafe}




\section{EPÍGRAFE}

TUDO O QUE HOJE PRECISO REALMENTE SABER, APRENDI NO JARDIM DE INFÂNCIA.

...Tudo o que hoje preciso realmente saber, sobre como viver, o que fazer e como ser, eu aprendi no jardim de infância. A sabedoria não se encontrava no topo de um curso de pós-graduação, mas no montinho de areia da escola de todo dia.

Estas são as coisas que aprendi lá:

1. Compartilhe tudo.

2. Jogue dentro das regras.

3. Não bata nos outros.

4. Coloque as coisas de volta onde pegou.

5. Arrume sua bagunça.

6. Não pegue as coisas dos outros.

7. Peça desculpas quando machucar alguém.

8. Lave as mãos antes de comer e agradeça a Deus antes de se deitar.

9. Dê descarga. (esse é importante)

10. Biscoitos quentinhos e leite fazem bem para você.

11. Respeite o outro.

12. Leve uma vida equilibrada: aprenda um pouco, pense um pouco... desenhe... pinte... cante... dance... brinque... trabalhe um pouco todos os dias.

13. Tire uma soneca a tarde; (isso é muito bom)

14. Quando sair, cuidado com os carros.

15. Dê a mão e fique junto.

16. Repare nas maravilhas da vida.

17. O peixinho dourado, o hamster, o camundongo branco e até mesmo a sementinha no copinho plástico, todos morrem... nós também.

...Pegue qualquer um desses itens, coloque-os em termos mais adultos e sofisticados e aplique-os à sua vida familiar, ao seu trabalho, ao seu governo, ao seu mundo e ai verá como ele é verdadeiro claro e firme.

...Pense como o mundo seria melhor se todos nós, no mundo todo, tivéssemos biscoitos e leite todos os dias por volta das três da tarde e pudéssemos nos deitar com um cobertorzinho para uma soneca.

...Ou se todos os governos tivessem como regra básica devolver as coisas ao lugar em que elas se encontravam e arrumassem a bagunça ao sair. Ao sair para o mundo é sempre melhor darmos as mãos e ficarmos juntos.

"É necessário abrir os olhos e perceber que as coisas boas estão dentro de nós, onde os sentimentos não precisam de motivos nem os desejos de razão. O importante é aproveitar o momento e aprender sua duração, pois a vida está nos olhos de quem souber ver". 
Dedicatória 


\title{
DEDICATÓRIA
}

\begin{abstract}
"Á minha amada mãe, Ana
Claudia Jarra Guimarães, por ter se doado em silêncio, se orgulhar e aceitar viver comigo o meu SONHO...
\end{abstract}

... e à minha "vida", Alexandre

França Tavares, por sua calma, amizade, carinho, compreensão, respeito, admiração, sorrisos e principalmente $O$ seu AMOR incondicional que me foram essenciais nos momentos difíceis". 
Agradecimentos Especiais 


\section{AGRADECIMENTOS ESPECIAIS}

\section{À Deus pela felicidade da tarefa cumprida.}

À minha família por contribuir afetivamente em mais um desafio da minha vida.

Aos meus tios José Miguel (Neto) e Vera Lúcia (Pingo), e à minha prima Maria Paula pelo abrigo durante esses dois anos, sem vocês esse sonho não teria sido concretizado.

À querida prima, amiga, companheira de todas as horas, Patrícia Mendes pela contribuição intelectual fundamental na análise dos resultados, e por estar sempre presente na minha vida dividindo as alegrias e tristezas desde o "Jardim de Infância". 
Agradecimentos 


\section{AGRADECIMENTOS}

Às amigas Monique Cesário e Adriana Helena de Almeida, pelas apresentações e incentivo.

À minha orientadora Maria Angélica Miglino, pois sem o seu incentivo esse trabalho não teria acontecido, e por nunca "fechar a porta" para quem tem "brilho nos olhos!"

Aos anatomistas Carlos Eduardo Ambrósio e à Daniele Martins, e por terem me aceitado como estagiária no canil, e no laboratório de células-troco o início de tudo.

Às amigas Cristiane Wenceslau e Karla Cardoso, que me ajudaram nos momentos de dificuldade e pelas alegrias, tristezas, desesperos, companhia nos congressos, nos plantões da madrugada, e nas coletas!

À todos os colegas do canil e da pós-graduação pelos dois anos de convivência e por compartilharem suas experiências.

À colega de "teatro" Érika Branco, pela sua idéia brilhante!

Ao amigo e Professor Doutor Alex Balduíno, por ter me aceitado em seu laboratório de braços abertos depois do teatro, pelos "burras", pelos conselhos, pela sua impaciente paciência...

À Professora Doutora Maria Eugênia Duarte, por me aceitar com carinho em seu laboratório.

Aos amigos Andréia, Ricardo, Marcela e Melissa, que com bondade me receberam e com muito entusiasmo trocaram seus conhecimentos e experiências na rotina do CTCel. 
Não podia deixar de agradecer, à amiga Fernanda Antunes, por ser uma pessoa muito especial em minha vida, que apesar da distância sempre se colocou à disposição e me ajudou a superar muitos obstáculos, e à sua mãe Irlete pela hospedagem.

Às amigas Ana Carolina Paiva e Giovana Muniz Carneiro, pelas horas de bate-papo no início do estágio "carioca" e pela hospedagem durante as coletas, amigas de longa data que jamais serão esquecidas!

Ao canil Auca Domus e sua proprietária e amiga Adriana Helena pelas coletas, bolos de chocolate e noites "eternas" de "plantão" no canil.

Ao canil Gama Grass e ao seu proprietário Gilberto pela colaboração e permissão das coletas.

Às clínicas veterinárias Clinicão (Guaratinguetá), Fintelman (Niterói), Animália (Rio de Janeiro), São Francisco (Petrópolis).

Às gestantes que mesmo sem saber doaram um material valioso por uma boa causa!

À Fundação de Amparo à Pesquisa do Estado de São Paulo - FAPESP pelo apoio financeiro. 
Resumo 


\section{RESUMO}

JARRA, J. Isolamento, quantificação e caracterização morfológica de células mesenquimais do sangue de cordão umbilical canino. [Isolation, quantification and morphologic characterization of mesenchymal cells from canine umbilical cord blood]. 2008. 74f. Dissertação (Mestrado em Ciências) - Faculdade de Medicina Veterinária e Zootecnia, Universidade de São Paulo, São Paulo, 2008.

Esse projeto tem como objetivo estabelecer técnicas de cultivo, isolamento, expansão e quantificação de células mesenquimais e hematopoéticas de sangue de cordão umbilical (SCU) de cães de raças variadas para aplicação em terapias celulares. Atualmente, vários tipos de células-tronco têm sido estudados devido a sua capacidade de diferenciação em diversos tecidos (HERZOG et al., 2003). O isolamento, quantificação e expansão dessas células permitem que a terapia celular seja utilizada na tentativa de tratamento em patologias (BARKER et al., 2003). Entre as fontes de células-tronco adultas (medula óssea, sangue periférico, tecido subcutâneo) mais precisamente as células progenitoras mesenquimais está o sangue de cordão umbilical. Sua principal função é o transporte de nutrientes e preencher as crescentes demandas de oxigênio da mãe para o feto (ALMEIDA et al., 2000). Neste estudo foi utilizado o sangue do cordão umbilical de cães ao nascimento, de 11 cadelas gestantes pesando entre 15 e $35 \mathrm{Kg}$. As células mesenquimais foram isoladas através da separação por gradiente de densidade com o reagente FICOLL, posteriormente o sangue foi diluído em PBS e centrifugado. $O$ pellet contendo células foi retirado e essas então acondicionadas em meio DMEM contendo $10 \%$ de soro fetal bovino e antibiótico, homogeneizadas e contadas através da câmara de Newbauer. As células foram então plaqueadas de acordo com o ensaio que seriam submetidas. Através do ensaio de CFU-F pudemos observar uma população de células aderentes isoladas da porção mononuclear do sangue de cordão umbilical que apresentou-se altamente heterogênea. Foram identificados, pelo menos, quatro tipos morfológicos distintos: células epitelióides grandes e pequenas; células de aspecto fusiforme; e células de aspecto estrelado e quando em confluência, as células apresentaram padrão de crescimento similar ao de miofibroblastos, normalmente observado em culturas de músculo liso e de estroma da medula óssea hematopoética. Na maioria das análises as colônias se 
apresentaram em número desejável, havendo uma variação de baixo a alto. Esse ensaio apresentou grande eficácia no isolamento, quantificação e caracterização morfológica das células mesenquimais obtidas a partir do sangue de cordão umbilical canino.

Palavras-chave: Células-tronco. Células mesenquimais. Sangue. Cordão umbilical. Canino. 
Abstract 


\begin{abstract}
JARRA, J. Isolation, quantification and morphologic characterization of mesenchymal cells from canine umbilical cord blood. [Isolamento, quantificação e caracterização morfológica de células mesenquimais do sangue de cordão umbilical canino]. 2008. 74f. Dissertação (Mestrado em Ciências) Faculdade de Medicina Veterinária e Zootecnia, Universidade de São Paulo, São Paulo, 2008.
\end{abstract}

This project has as objective established cultivation techniques, isolation, expansion and quantification of mesenchymal cells from umbilical cord blood (UCB) of dogs of varied breeds for application in cellular therapies. Nowadays, several cell-trunk types have been studied due to his/her differentiation capacity in several woven (HERZOG et al., 2003). The isolation, quantification and expansion of those cells allow the cellular therapy to be used in the treatment attempt in pathologies (BARKER et al., 2003). Among the adult cell-trunk sources (bone marrow, peripheral blood, subcutaneous tissue) more precisely the progenitors mesenchymal cells are the umbilical cord blood. Her main function is the transport of nutrients and to fill out the crescents demands of the mother's oxygen for the fetus (ALMEIDA et al., 2000). In this study, the blood was used from the umbilical cord of dogs to the birth, of 11 pregnant female dogs weighing between 15 and $35 \mathrm{Kg}$, the mesenchymal cells were isolated through the separation for density gradient with the reagent FICOLL, later the blood was diluted in PBS and centrifuged according to protocol, the pellet containing cells was removed and those then conditioned in half DMEM containing $10 \%$ of bovine fetal serum and antibiotic, homogenized and counted through the camera of Newbauer. They were plated then in agreement with the rehearsal that they would be submitted. Through the rehearsal of CFU-F (Colony Forming Unit - Fibroblast) we could observe a population of isolated adherent cells of the mononuclear population of the umbilical cord blood that came highly heterogeneous. They were identified, at least, four different morphologies: big and small epithelial cells; aspect fusiforme; and cells of starry aspect and when in confluence, the cells presented pattern of similar growth to the of miofibroblastos, usually observed in cultures of flat muscle and of stromal of the hematopoietic bone marrow. In most of the analyses the colonies came in 
desirable number, having a variation of low the high. That rehearsal presented great effectiveness in the isolation, quantification and morphologic characterization of the mesenchymal cells obtained starting from the umbilical cord blood of canine.

Key words: Stem cells. Mesenchymal cells. Blood. Umbilical cord. Canine 


\section{SUMÁRIO}

1 Introdução

2 Revisão de Literatura

3 Material e Método 35

3.1 Coleta e processamento do sangue de cordão umbilical. 36

3.2 Protocolos de suplementação dos meios de cultura

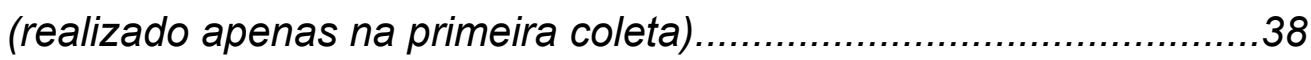

3.3 Ensaio de CFU-F (Colony Forming Unit- Fibroblast)..................39

3.4 Ensaio para determinação da eficiência de formação de colônias (CFE) 40

3.5 Ensaio para indução "in vitro" de diferenciação osteogênica e adipogênica. 41

4 Resultados

4.1 Obtenção de Células Mesenquimais do Sangue de Cordão Umbilical Canino. 44

4.2 Identificação e Quantificação de Progenitores

Mesenquimais - CFU-F. 45

4.3 Análise dos Diâmetros das Colônias Formadas............................50

4.4 Avaliação da Eficiência de Formação de Colônias (CFE)...............54

4.5 Ensaio para Indução "in vitro" de Diferenciação

Osteogênica e Adipogênica.

5 Discussão

6 Conclusão 64

7 Considerações Finais. 66

8 Referências 
Introdução 


\section{INTRODUÇÃO}

Atualmente, vários tipos de células-tronco têm sido estudados devido a sua capacidade de diferenciação em diversos tecidos, tais como fígado, sistema nervoso central, rins, pâncreas, pulmões, pele, trato gastrointestinal, coração e músculo esquelético (HERZOG et al., 2003). O isolamento, quantificação e expansão dessas células permitem que a terapia celular seja utilizada na tentativa de tratamento em patologias que afetam o homem e os animais (BARKER et al., 2003).

Entre as fontes de células-tronco adultas (medula óssea, sangue periférico, tecido subcutâneo) mais precisamente as células progenitoras mesenquimais está o sangue de cordão umbilical. Sua principal função é o transporte de nutrientes e preencher as crescentes demandas de oxigênio da mãe para o feto (ALMEIDA et al., 2000).

Por se tratar de um assunto muito complexo, e de uma grande variedade de tipos celulares presentes nessa fonte (sangue de cordão umbilical) daremos enfoque às células-tronco mesenquimais. Esse tipo celular participa da maior parte das estratégias em terapia, já que possui grande plasticidade.

A aplicação da terapia celular em humanos requer procedimento prévio e similar em modelos animais. Pouco progresso, entretanto tem sido alcançado no isolamento e quantificação dessas células, ou mesmo nas técnicas relativas ao seu cultivo e expansão na espécie canina.

As células mesenquimais obtidas a partir do sangue de cordão umbilical apresentaram vantagens sobre as células obtidas da medula óssea, por serem coletadas durante o nascimento, sem necessidade de sedação ou anestesia para seu procedimento, nem analgesia após a coleta. Não há dano ao recém-nascido durante a obtenção do sangue, conforme descrito por alguns autores (KII-SOO PARK et al., 2006 e LU-LU LU et al., 2006; RUBSTEIN et al., 1995). Essas células também se apresentam imaturas em relação às células obtidas da medula óssea e poderiam ser utilizadas como uma rica fonte para transplantes autólogos (KII-SOO PARK et al., 2006 e LU-LU LU et al., 2006).

Por possuírem uma semelhança em relação à população celular, a medula óssea e o sangue circulante no cordão umbilical da espécie humana estão sendo estudados, já que as duas fontes possuem células precursoras mesenquimais 
passíveis de indução à diferenciação para serem posteriormente utilizadas em terapias resultando numa possível regeneração tecidual.

Uma hipótese é que essa mesma população celular esteja circulante no sangue do cordão umbilical da espécie canina servindo então como fonte para futuras terapias na espécie.

O objetivo do trabalho foi avaliar o comportamento das células progenitores mesenquimais provenientes do sangue de cordão umbilical de cães. 
Revisão de Literatura 


\section{Revisão de Literatura}

O sangue é constituído por uma variedade de células em suspensão em meio líquido, chamado plasma. Funciona principalmente como um veículo para o transporte de gases, nutrientes, produtos metabólicos de excreção, células e hormônios por todo o corpo.

Todas as células sangüíneas são formadas na medula óssea, através de um processo conhecido como hematopoese e são divididas em três principais classes funcionais: 1) células sanguíneas vermelhas (eritrócitos), 2) células sanguíneas brancas (leucócitos), e 3) plaquetas (trombócitos) (JUNQUEIRA; CARNEIRO, 1999).

A hematopoese é o processo pelo qual as células sanguíneas maduras desenvolvem-se a partir de células precursoras. Os primeiros indícios da hematopoese são extra-embrionários. Nessa fase, que se inicia em torno do primeiro décimo da gestação, surgem as primeiras ilhas de células eritropoéticas formadoras de hemoglobina no saco vitelino, junto com as primeiras células precursoras dos leucócitos. Em seguida vem a hematopoese embrionária, que começa no final do primeiro terço da gestação e compõe-se de três etapas. A primeira é a hepática, quando a eritropoese predomina no fígado, enquanto que a leucopoese se torna mais evidente. A seguir vem a etapa esplênica e a linfática, quando isso ocorre também no baço e nos órgãos linfáticos. A terceira e última etapa é a medular, que começa aproximadamente na metade da gestação e perdura pelo resto da vida (GARCIA-NAVARRO, 2005).

Ao nascimento, a hematopoese ocorre quase que exclusivamente na medula óssea, apesar do fígado e do baço poder retomar a atividade quando houver necessidade (GARCIA-NAVARRO, 2005). 
Após o nascimento, a hematopoese limita-se exclusivamente à medula óssea e compreende duas etapas. A primeira é a etapa infantil, que envolve a medula e todos os ossos e a segunda, a etapa adulta, com a atividade hematopoética limitada à medula dos ossos chatos e as extremidades dos ossos longos. Nesta fase, as demais medulas ósseas tornam-se amarelas, isto é, são tomadas por tecido adiposo. Em casos de necessidade, porém, a medula amarela volta a ser vermelha ou eritropoética. Os demais órgãos que desempenham papéis hematopoéticos na vida pré-natal, como o baço, o fígado e os nódulos linfáticos podem voltar a exercer esta função. Essa metaplasia eritropoética, que ocorre geralmente nas anemias ferroprivas importantes, é chamada regeneração extra-medular da série vermelha (GARCIA-NAVARRO, 2005).

Do nascimento à maturidade, o número de sítios ativos de hematopoese na medula óssea diminui, mas mantêm o seu potencial de atividade (SCOTT, 1991). Já no homem adulto, a hematopoese ocorre na medula óssea, sobretudo do crânio, das costelas, do esterno, da coluna vertebral, da pelve e nas extremidades proximais dos ossos longos (GARCIA-NAVARRO, 2005).

Uma das possibilidades para estudar a hematopoese são os sistemas de cultura in vitro, onde as células progenitoras são caracterizadas pela sua capacidade de formar colônias celulares ou CFUs (Colony Forming Units). A taxa de divisão dessas células é modulada por hormônios chamados poetinas, por fatores estimuladores das colônias e interleucinas produzidas localmente (JUNQUEIRA; CARNEIRO, 1999).

As células-tronco hematopoéticas (CTHs) ou células precursoras hematopoéticas da medula óssea são capazes de formar a CFUe (Colony Forming Unit erythrocitic ou Unidade Formadora de Colônias eritrocíticas), a qual, dá origem 
ao rubroblasto ou pró-eritroblasto, que é a primeira célula identificada da série vermelha, o pró-eritroblasto através do amadurecimento e divisões origina o prórubrócito ou eritroblasto, posteriormente o rubrócito, e o meta-rubrócito. Em seguida, a célula não se multiplica mais, perde o núcleo, passa por uma fase rápida de reticulócito e finalmente, atinge a maturidade circulatória como eritrócito (GARCIANAVARRO, 2005).

Essas células são capazes de formar também UFCmm (Unidade Formadora de Colônias mielomonocíticas) a qual pode dar origem, indistintamente, ao mieloblasto ou ao monoblasto. O mieloblasto passa pela fase de pró-mielócito onde poderá dar origem a três tipos celulares diferentes: o eosinófilo, o basófilo e o mielócito neutrófilo. Esse último passa pelas fases de metamielócito neutrófilo, bastonete neutrófilo e segmentado neutrófilo para finalmente ser denominado neutrófilo. Os neutrófilos podem envelhecer degenerar-se e morrer na circulação. A UFCmm pode ainda dar origem ao monoblasto, que envelhece na forma de monócito circulante (GARCIA-NAVARRO, 2005).

A célula UFCmg (Unidade Formadora de Colônias megacariocíticas) dá origem ao megacarioblasto e posteriormente ao megacariócito que possui um citoplasma grande de onde se desprenderão as plaquetas (GARCIA-NAVARRO, 2005).

A célula progenitora forma também uma célula que migra para os tecidos linfáticos, onde dará origem aos linfoblastos os quais ao passarem por uma fase de pró-linfócito após amadurecimento chegam à fase de linfócito onde terão a capacidade de originar os linfócitos T, os linfócitos B e as células NK (natural killer). Os linfócitos circulam por mais tempo que os demais glóbulos brancos e podem, quando estimulados por determinados antígenos, sofrer transformação e voltarem à 
condição de linfoblastos e multiplicar-se outra vez (WEISSMAN., 2000; PASSEGUE et al., 2003; GARCIA-NAVARRO., 2005).

Todos os tipos de células sanguíneas derivam de um único tipo primitivo de célula-tronco, chamado célula-tronco hematopoética que podem ser identificadas das seguintes formas:

As células-tronco hematopoéticas da medula óssea podem ser isoladas através de sistemas de cultura semi-sólidas, com gel de agarose ou ainda metilcelulose contendo várias combinações de fatores de crescimento que determinarão diferentes tipos de progenitores hematopoéticos através da formação de colônias (DEXTER et al., 1977).

Essas colônias são formadas após 14 a 21 dias devido à baixa densidade celular plaqueada por amostra, as mesmas ficam "presas" no gel e podem ser analisadas morfologicamente sob as seguintes condições: BFU-E (burst forming uniterythroid), CFU-G (colony forming unit-granulocyte), CFU-GM (colony forming unitgranulocyte-macrophage), CFU-GEMM (colony forming units-granulocyte, erythroid, macrophage, megakaryocyte) como citado anteriormente. Dependendo da morfologia da colônia encontrada conheceremos a freqüência das células progenitoras da amostra original (DEXTER et al., 1977 SUTHERLAND et al., 1994).

Existem também outras formas de isolamento dessas células tais como, o cobbllestone área-forming cells (CAFCs) onde as células-tronco hematopoéticas são cultivadas sob camadas estromais, permitindo a proliferação das mesmas (PLOEMACHER., 1989). Isso ocorre, pois existe além de uma simples correlação, uma dependência entre as células de linhagem hematopoéticas e células estromais. Estas células compõem um microambiente no interior da medula óssea (BIANCO, 2001). 
Através da imunofenotipagem, transplantando células progenitoras hematopoéticas de camundongos GFP (green fluorescent protein) em receptores letalmente irradiados, a presença do marcador verde permite que a distribuição da célula seja posteriormente analisada (CAMARGO et al., 2004).

A citometria de fluxo também denominada separação por FACS Fluorescence Activated Cell Sorter, (ALBERTS., 2004) é uma das formas de avaliação fenotípica (reflexo da expressão gênica) seguida pela quantificação das células-tronco hematopoéticas (GROTTO; NORONHA., 2003) que serão melhor descritas posteriormente.

Essas células estão presentes além da medula óssea, também no sangue periférico e sangue de cordão umbilical (NAKAGE, 2006).

O cordão umbilical é um anexo placentário exclusivo dos mamíferos que permite a comunicação entre o embrião e a placenta. Na espécie canina é um cordão curto contendo vasos sanguíneos calibrosos circundados por material gelatinoso. Embora possa haver variação entre espécies, ele apresenta duas artérias e uma veia que garantem a nutrição e respiração do embrião. Ele é formado a partir do saco amniótico, também responsável pela formação do epitélio do cordão e pelo alantóide, responsável pela formação dos vasos umbilicais e vesícula vitelínica (CARVALHO et al., 2001).

Nos carnívoros a placenta é classificada quanto ao arranjo das membranas fetais como cório-vitelínica; quanto a forma da área de junção materno-fetal, pode ser classificada como zonária anular ou circular; e quanto a camada de barreiras inter-hemática, como endotéliocoreal devido o íntimo contato do trofoblasto com o endotélio materno (sinsiciotrofoblasto e citotrofoblasto). São também denominados deciduais por haver o desprendimento de tecidos uterinos e endometriais durante o 
parto (NAKAGE, 2005).

O fluxo materno-fetal dos carnívoros é classificado como fluxo em corrente secundária simples, devido os capilares maternos e fetais se apresentarem de forma perpendicular com relação ao fluxo sanguíneo principal na área das trocas (LEISSER; KAUFFMANN., 1994; LEE et al., 1983). Não há mistura de sangue arterial e venoso no funículo umbilical e na placenta, devido à ausência de anastomoses entre os vasos sanguíneos (NAKAGE, 2005).

O feto fica no interior de uma bolsa com líquido amniótico, sendo, a comunicação entre o feto e a placenta feita através do cordão umbilical. O nível do fluxo sangüíneo umbilical aumenta com a progressão da gestação para preencher as crescentes demandas de oxigênio e nutrientes do feto. $O$ aumento desse fluxo é atingido por diminuição da resistência vascular umbilical nos primórdios da gestação e posteriormente por aumento da pressão sangüínea arterial (ALMEIDA et al., 2000).

No sangue de cordão umbilical humano estão presentes as células-tronco hematopoéticas com maior potencial proliferativo em relação às células-tronco da medula óssea e do sangue periférico (NAKAGE, 2006).

As células-tronco têm basicamente duas características importantes que as distinguem de outros tipos celulares. São células não especializadas que se renovam por períodos longos, por meio de divisões celulares assimétricas e, sob certas condições fisiológicas ou experimentais, elas podem ser induzidas à diferenciação em vários tipos de tecido (DEL CARLO, 2005).

Ontogenicamente, a hematopoese se inicia na aorta ventral e no saco vitelínico fetal. Em humanos, num segundo momento, elas atingem a medula óssea no final do segundo trimestre gestacional. Há relatos de que as células-tronco 
hemopoéticas do cordão umbilical contêm grande quantidade de células progenitoras (BACKER; WAGNER., 2003).

Eis ainda autores que definem dois tipos de células-tronco hematopoéticas encontradas na medula óssea de camundongos: as células-tronco de longa duração (LT-HSCs Long-Term Hematopoietic Stem Cells) e as células-tronco de curta duração (ST-HSCs Short-Term Hematopoetic Stem Cells) (CHRISTENSEN; WEISSMAN., 2001).

As células-tronco de longa-duração são definidas por sua capacidade de diferenciar em linhagens linfóide e mieloeritróide quando transplantadas em camundongos letalmente irradiados, as duas classes de precursores pertencentes as maiores linhagens de células sanguíneas. Como descrito anteriormente os precursores linfóides darão origem às células $\mathrm{B}, \mathrm{T}$ e natural killer (NK), enquanto os precursores mielóides darão origem a monócitos e macrófagos, neutrófilos, eosinófilos, basófilos, megacariócitos e eritrócitos por mais de seis meses quando transplantadas em camundongos letalmente irradiados (WEISSMAN; 2000).

Essas células originam as células-tronco de curta-duração, que possuem uma capacidade limitada de auto-renovação e formarão as células hematopoéticas individualizadas. Após essa diferenciação são formados os progenitores multipotentes, que perdem a capacidade de auto-renovação, mas mantém a multipotencialidade (CHRISTENSEN; WEISSMAN., 2001; JIN-FU WANG et al., 2005).

Em camundongos jovens, estima-se que 8 a $10 \%$ dessas células hematopoéticas de longa duração entram no ciclo celular e dividem-se a cada dia, enquanto as células de curta duração proliferam-se por tempo limitado possivelmente por poucos meses (12 semanas) (WEISSMAN, 2000). 
As células-tronco de longa duração apresentam altos níveis de atividade da telomerase (enzima que ajuda a manter o comprimento no final do cromossomo chamado de telômeros, pela adição dos nucleotídeos). A telomerase em atividade é uma característica de células indiferenciadas, em divisão e células cancerígenas. Células somáticas humanas em diferenciação, ao contrário das células de camundongo não demonstram telomerase em atividade (WEISSMAN, 2000).

As células-tronco de curta duração formam uma população heterogênea que se diferem significativamente entre si em termos de habilidade, auto-renovação e repopulação do sistema hematopoético (WEISSMAN, 2000).

As células-tronco hematopoéticas, consideradas células-tronco adultas, têm sido amplamente utilizadas uma vez que podem ser isoladas do sangue, manipuladas in vitro e devolvidas para a circulação, representando uma ferramenta valiosa para aplicação em terapias celulares de diferentes tipos de patologias (TORRENTE et al, 2004).

Alguns autores afirmam que a quantidade dessas células progenitoras extraídas do cordão umbilical é insuficiente para o sucesso do transplante, e sugerem a realização da expansão dessas células in vitro, em meio de cultura condicionada com citocinas específicas (BROXMEYER et al., 1990).

As condições para isolamento de células-tronco diferem segundo a sua origem. Quando isoladas uniformemente de algum tecido, os protocolos de enriquecimento são diferentes para cada tipo de célula bem como as condições de cultivo (ULLOA-MONTOYA et al., 2005).

A influência do ambiente na cultura é expressa por quatro fatores. O primeiro deles é a natureza do substrato ou a fase em que cada célula cresce, isto é, 1) substrato sólido, monocamada de crescimento em plástico, 2) meio semi-sólido 
como gel de colágeno ou ágar, ou ainda 3) cultura líquida em suspensão; O segundo deles de acordo com a constituição fisiológica e fisico-química do meio; O terceiro de acordo com a constituição da fase de gás e finalmente, o quarto e último, temperatura de incubação (FRESHNEY, 1994).

O cultivo de células tem três objetivos: sustentar o potencial de regeneração das células-tronco, manter a capacidade de diferenciação e permitir sua criopreservação (ULLOA-MONTOYA et al., 2005).

As células-tronco embrionárias possuem uma grande capacidade de autorenovação e diferenciação, e são rotineiramente isoladas e cultivadas na presença de uma camada de substrato onde crescem como colônias (ULLOA-MONTOYA et al., 2005).

As células-tronco adultas também têm o potencial de auto-renovação e diferenciação, porém mais restrito do que o das células-tronco embrionárias. Por esta característica podem ser chamadas de células-tronco multipotentes. Dentro desse grupo podemos incluir as células-tronco hematopoéticas, capazes de se diferenciar em oito tipos de células sanguíneas e as células-tronco mesenquimais que podem se diferenciar em fibroblastos, osteoblastos, condroblastos, adipócitos e músculo esquelético (ULLOA-MONTOYA et al., 2005).

Recentemente, as células-tronco mesenquimais (CTMs) têm atraído a atenção de vários pesquisadores, pois são de grande interesse para serem usadas no tratamento de diversas doenças. Muitos estudos têm isolado as CTMs e tem controlado, in vitro, sua diferenciação em tecido cartilaginoso e ósseo utilizando indutores específicos, com objetivo de usar essa nova tecnologia no reparo desses tecidos lesados (BITTENCOURT et al., 2006).

O transplante de células mesenquimais tem algumas vantagens sobre o 
transplante de medula óssea total: 1) grande número de precursores mesenquimais são coletados por $\mathrm{mL}$ de medula óssea, logo, um maior número de células mesenquimais são geradas à partir dessas células precursoras; 2) em condições apropriadas de temperatura, $\mathrm{pH}$, porcentagem de gás carbônico, oxigênio e nutrientes essas células precursoras mantém sua multipotencialidade, longa capacidade de cultivo e múltiplas passagens in vitro, demonstrando seu potencial "tronco" e mantendo a habilidade de auto-renovação e 3) as células-tronco mesenquimais formam osso mais rapidamente do que as células mononucleares extraídas da medula óssea, podendo ser perfeitamente aplicadas em casos de deficiências ósseas aumentando o sucesso dessa terapia (KREBSBACH et al., 1999).

A maioria das culturas in vitro de células de vertebrados cresce em monocamada ou sobre substrato artificial. O crescimento espontâneo em suspensão é restrito às células hematopoéticas e tumores de roedores (FRESHNEY, 1994). Um outro fator determinante do crescimento celular é o $\mathrm{pH}$ do meio de cultura. Algumas linhagens de fibroblastos proliferam em meio com pH entre 7.4-7.7, enquanto células diferenciadas proliferam em pH entre 7.0 e 7.4 e ainda algumas células epidérmicas que podem ser mantidas em pH 5.5 (FRESHNEY, 1994).

As culturas devem ser mantidas a uma temperatura $36,5{ }^{\circ} \mathrm{C}$, pois temperaturas baixas dificultam a dissolução do $\mathrm{CO}_{2}$ nos tecidos e células. $\mathrm{O}$ gás carbônico $\left(\mathrm{CO}_{2}\right)$ a $5 \%$ é utilizado para mimetizar as condições fisiológicas do organismo; já que o mesmo utiliza $\mathrm{o}^{\mathrm{CO}_{2}}$ em maior quantidade do que $\mathrm{o} \mathrm{O}_{2}$ (FRESHNEY, 1994).

Como descrito por Friedenstein, Piatetzky e Petrakova (1966) e Friedenstein et al (1968), as células mesenquimais estão presentes na medula óssea. O autor 
também identificou a presença de progenitores multipotentes mesenquimais capazes de se diferenciar em múltiplos tecidos mesodermais.

Dentro de uma população de células provenientes do sangue do cordão umbilical, estão presentes e podem ser coletadas concomitantemente as células progenitoras de linhagem mesenquimal que darão origem aos CFU-Fs do inglês colony-forming-unit-fibroblast (unidade formadora de colônia de fibroblastos) (FRIEDENSTEIN, PIATETZKY E PETRAKOVA., 1966 e FRIEDENSTEIN et al., 1968.

Essas células mesenquimais aderem à placa de cultura, assemelham-se aos fibroblastos "in vitro", e formam colônias (BITTENCOURT et al., 2006). As colônias são formadas a partir de uma única célula em suspensão, e quando plaqueadas em altas concentrações formam uma monocamada celular no substrato (placas de cultura) (KREBSBACH et al.,1999).

As células mesenquimais são capazes de proliferar por 25 replicações in vitro. O crescimento ocorre sob a influência de fatores de crescimento derivados do plaqueamento (PDGF- plated-derived growth factor), fator de crescimento epidermal (EGF- epidermal growth factor) e fator de crescimento da insulina (IGF-1- insulin-like growth factor) (BIANCO., 2001).

Por aderirem à placa de cultivo, as células mesenquimais que compõem grande parte do sistema estromal, podem ser isoladas e separadas das célulastronco hematopoéticas, não aderentes, através de repetidas lavagens (SATOMURA et al., 2000 e MURAGLIA et al., 2003).

Uma das formas de avaliação fenotípica (reflexo da expressão gênica) e quantificação das células progenitoras mesenquimais em uma amostra é a análise através de citometria de fluxo (GROTTO; NORONHA., 2003). A citometria de fluxo é um recurso emergente na medicina veterinária que permite uma análise rápida, 
objetiva e quantitativa de células em suspensão. As células marcadas com anticorpos monoclonais específicos, permitem a identificação e quantificação baseadas no seu tamanho, granulosidade e intensidade de fluorescência (NAKAGE et al., 2005). Também chamada de separação de células ativadas por fluorescência, ou FACS -Fluorescence Activated Cell Sorter (ALBERTS et al., 2004) como descrito anteriormente.

As células mesenquimais oriundas da medula óssea humana expressam CD105, SH3, Stro-1 e CD13, marcadores importantes para sua identificação e são CD45- isto é, não expressam o marcador CD45, que indica a marcação de células da linhagem hematopoética. Em estudos clonais as células progenitoras apresentam potencial osteogênico, condrogênico e adipogênico, considerando que de 60 a $80 \%$ dessas células apresentam potencial osteogênico e condrogênico, e praticamente todos os clones exibem potencial osteogênico (ULLOA-MONTOYA, 2005).

Em 2006, Balduíno descreveu que as “células mesenquimais da medula óssea humana adulta que expressam o marcador de superfície CD146 (MCAM) são multipotentes e têm a capacidade de auto-renovação, indicando a existência e caracterização de uma legítima célula-tronco mesenquimal”.

Autores afirmam além isso, existência de osteoprogenitores na medula óssea e asseguram que essas células são capazes de reparar defeitos ósseos em vários modelos animais como, por exemplo, nos cães (MANKANI, 2006).

As células de uma amostra em suspensão são marcadas com reagentes fluorescentes específicos para detecção de moléculas de superfície e são introduzidas numa câmara de fluxo vibratória. Cada célula é avaliada com relação ao tamanho (dispersor de luz anterior), granulosidade (dispersor de $90^{\circ}$ ), e intensidade de fluorescência para a detecção de antígenos de superfície diferentes 
(imunofenotipagem). A imunofenotipagem consiste no isolamento de populações de células distintas com diferentes antígenos de superfície marcados com anticorpos fluorescentes específicos (NAKAGE et al., 2005).

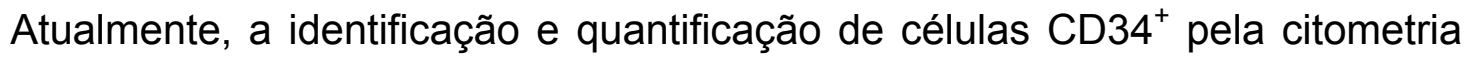
de fluxo aplicada em células coletadas do sangue do cordão umbilical em cães, avaliam a capacidade de reconstituição hematopoética das células-tronco caninas para realização de transplantes de medula óssea e permite o emprego do modelo canino em vários estudos e experimentos terapêuticos pré-clínicos no transplante de medula óssea em humanos (NAKAGE et al., 2005).

Matikainen em 2005 sugere que as células-tronco adultas do sangue de cordão umbilical também podem ser isoladas e induzidas à diferenciação de outros tecidos além do sanguíneo com a utilização de técnicas e meios de cultura adequados, como por exemplo, células das três camadas germinativas; células neurais, hepatócitos, osteoblastos e adipócitos. Kii-Soo Park et al, 2006 afirmam ainda que essas células sejam prematuras em relação às células mesenquimais da medula óssea e consequentemente mais eficazes se utilizadas em terapias para a regeneração desses tecidos.

Do mesmo modo, Tse e Laughlin 2005 asseguram que o sangue de cordão umbilical é uma fonte disponível rica em células-tronco, a qual não provoca risco à mãe nem ao neonato. Sua coleta não está associada a preocupações éticas como a de células-tronco embrionárias. O material pode ser criopreservado, armazenado em bancos de sangue cordão umbilical e utilizado de forma autóloga em pacientes com patologias instáveis, excluindo possíveis dificuldades decorrentes da coleta de medula óssea desse paciente, além disso, diminuindo o risco de contaminação viral ou infecção. 
Material \& Método 


\section{Material \& Método}

3.1 Coleta e processamento do sangue de cordão umbilical.

Foram utilizadas 11 cadelas fêmeas gestantes: três SRD, duas da raça Bull Dog Inglês, uma Pug, três da raça Boxer, uma Husky Siberiano e uma Schnauzer miniatura, pesando entre 15 e $35 \mathrm{~kg}$ provenientes de canis e clínicas veterinárias particulares. Ao nascimento dos cães, coletamos em média $7,75 \mathrm{~mL}$ (volume variando de 0,5 a $15 \mathrm{~mL}$ ) de sangue do cordão umbilical através da punção dos vasos umbilicais conforme Figura 1 . O material foi coletado em seringas de 3,5 e 10 $\mathrm{mL}$, com agulhas $25 \times 0,7$ e $30 \times 0,8$ previamente rinsadas com heparina ${ }^{1}$. O material coletado foi mantido sob refrigeração $\left(4^{\circ} \mathrm{C}\right)$ e posteriormente dividido aleatoriamente

e encaminhado para processamento no Instituto Nacional de Traumatologia e Ortopedia no Rio de Janeiro (INTO-RJ) ou no Laboratório de Células-tronco do departamento de cirurgia da Faculdade de Medicina Veterinária e Zootecnia da Universidade de São Paulo.

\footnotetext{
${ }^{1}$ Heparin, 5mL, 5000UI/mL, Cristália Produtos Quimicos Farmacêuticos Ltda, São Paulo
} 


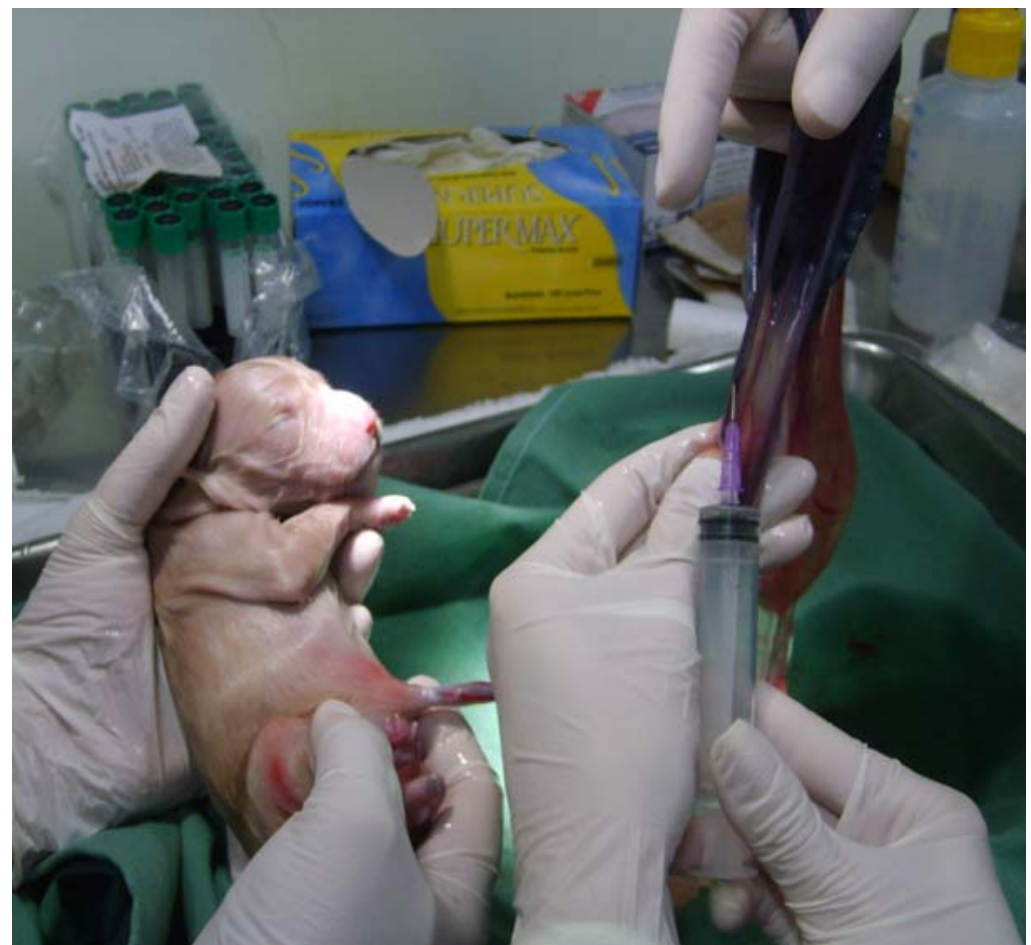

Figura 1 - Coleta de sangue de cordão umbilical em filhote de SRD

A separação das células foi feita no sangue total proveniente do cordão umbilical, por gradiente de densidade obedecendo ao protocolo descrito a seguir. Após a separação com reagente $\mathrm{FICOLL}^{2}$, o sangue foi diluído em PBS na proporção 1:3. Foi então feita centrifugação (1500 rpm, por 25 minutos a $22^{\circ} \mathrm{C}$ ) e, as células nucleadas localizadas em um "anel” na interface com a camada de hemácias foram retiradas (Figura 2). As células foram novamente centrifugadas (2000 rpm por 5 minutos a $4^{\circ} \mathrm{C}$ ) e o pellet contendo algumas hemácias e células mononucleares foi homogeneizado para nova centrifugação. A nova centrifugação foi feita a 2000 rpm, por 5 minutos a $4^{\circ} \mathrm{C}$. As células foram então acondicionadas em meio de cultura DMEM $^{3}$ suplementado com $10 \%$ de soro fetal bovino ${ }^{4}$ (SFB) e $50 \mathrm{~g} / \mathrm{mL}$ de ciprofloxacina, homogeneizadas e contadas, para o cálculo do número de células foi utilizada a seguinte equação matemática: $\mathrm{NC} / \mathrm{nQ} \times \mathrm{D} \times 10^{4}$ onde $\mathrm{NC} / \mathrm{nQ}$ corresponde

\footnotetext{
${ }^{2}$ Ficoll-Paque, 0.12EU/mL, GE Healthcare Bio-Sciences AB, Sweden Lote 71-1019-00 EE

${ }^{3}$ Meio Dulbecco Mem, 10,15 gramas/L, Cultilab Material para Cultura Celular Ltda, São Paulo

${ }^{4}$ Soro fetal Bovino, $10 \mathrm{~mL}$, Cultilab Material para Cultura Celular Ltda, São Paulo.
} 
ao número de células vitais contadas dividido pelo número de quadrados da câmara de Newbauer utilizados na contagem das células, e D corresponde a diluição da amostra. Foram então plaqueadas de acordo com o ensaio que seriam submetidas.

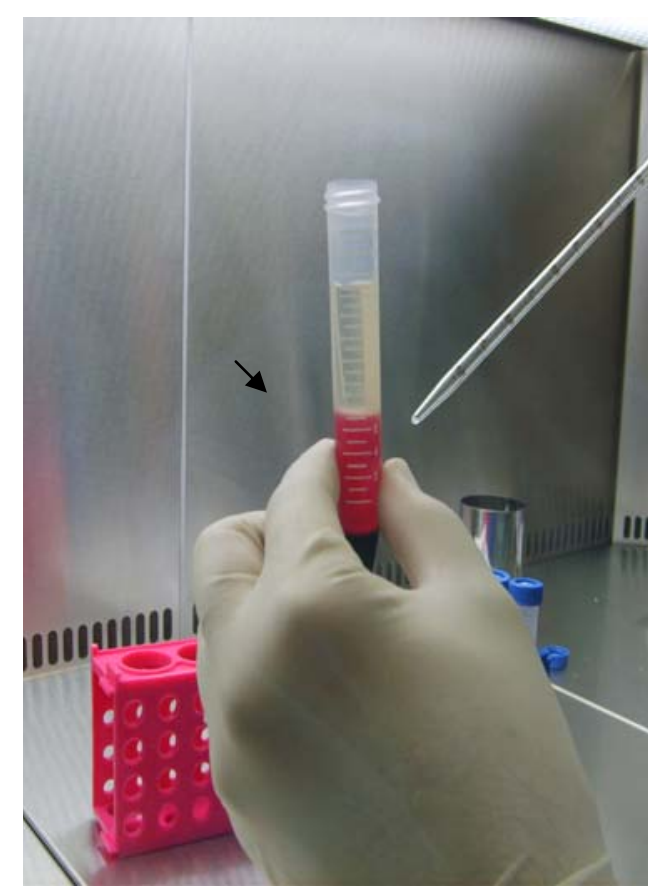

Figura 2 - O anel (indicado pela seta) contendo células mononucleares.

3.2 Protocolos de suplementação dos meios de cultura (realizado apenas na primeira coleta)

As células isoladas segundo o protocolo descrito acima foram acondicionadas nos seguintes meios de cultura:

a) DMEM suplementado com $10 \%$ de soro fetal bovino, $1 \%$ penicilina ${ }^{5}, 1 \%$ fitohemaglutinina ${ }^{6}$ e $25 \mathrm{mM}$ HEPES$^{7}$;

\footnotetext{
${ }^{5}$ 100U/ml, Gibco, Invitrogen Corporation, NY, USA.

${ }^{6} \mathrm{MPH}-\mathrm{A}$, Fr. 10mL, Cultlab Material para Cultura Celular, Ltda, São Paulo

${ }^{7}$ N-2-Hydroxyethylpiperazine-N'-2-Ethane Sulfonic Acid, Gibco, Invitrogen Corporation, NY, USA, partida p1501
} 
b) DMEM suplementado com $10 \%$ de soro fetal bovino, $1 \%$ penicilina, $1 \%$ aminoácidos $^{8}$ essenciais, $2 \mathrm{mM}$ L-glutamina ${ }^{9}$ e $25 \mathrm{mM}$ HEPES;

c) RPMI suplementado com $10 \%$ de soro fetal bovino, $1 \%$ penicilina, $1 \%$ fitohemaglutinina, 25mM HEPES;

d) RPMI suplementado com $10 \%$ de soro fetal bovino, $1 \%$ penicilina, 1\%aminoácidos, 2mM L-glutamina e 25mM HEPES;

Para a expansão das células mesenquimais foi utilizado DMEM suplementado com $10 \%$ de SFB e $1 \%$ de penicilina. As células foram mantidas em cultura por cerca de 60 dias. Após este período de expansão as células foram tripsinizadas e centrifugadas. O pellet obtido por centrifugação, foi homogeneizado e congelado em meio crioprotetor contendo DMSO.

Cada amostra foi congelada em alíquotas de $1 \mathrm{~mL}$ em três criotubos contendo $4,2 \times 10^{4}, 15 \times 10^{4}$ e $48,5 \times 10^{4}$ células respectivamente.

\subsection{Ensaio de CFU-F (Colony Forming Unit- Fibroblast)}

Para determinar a capacidade de formação de colônias fibroblásticas e determinar a quantidade aproximada ideal para a espécie em questão (CFU-Fs) foram plaqueadas três garrafas de cultura de $25 \mathrm{~cm}^{2}$ contendo $2,5 \times 10^{5}$ células/garrafa, três garrafas contendo $5 \times 10^{5}$ células e três garrafas contendo $1 \times 10^{6}$ células. Após três dias de cultivo as células foram lavadas com meio suplementado

\footnotetext{
${ }^{8}$ Sigma Chemical CO, MO, USA.

${ }^{9}$ L-glutamina, $2 \mathrm{MM} / \mathrm{mL}$, Cultilab Material para Cultura Celular Ltda, São Paulo.
} 
com SFB e antibióticos. A troca de meio era realizada a cada cinco dias e mantidas com meio fresco. Após um período de 13 dias as células foram fixadas overnight na própria garrafa de cultura com formol tamponado a $4 \%$ a $4^{\circ}$ C. Após fixação as células foram coradas por 12 horas com cristal violeta e secas em temperatura ambiente, posteriormente as colônias formadas foram contadas,e $30 \%$ dessas colônias tiveram seu diâmetro aferido. As células foram então fotografadas em aumento de 10X, e as garrafas escaneadas para posterior análise.

Com todo o material obtido de outras amostras, foram plaqueadas mais de uma garrafa de $25 \mathrm{~cm}^{2}$ contendo $5 \times 10^{5}$ células. Seguindo o protocolo supracitado.

\subsection{Ensaio para determinação da eficiência de formação de colônias (CFE)}

Após o ensaio de CFU-F, as amostras foram utilizadas para determinação da eficiência de formação de colônias. O protocolo foi adaptado a partir do utilizado para células humanas que corresponde a um valor numérico de 10-50 CFU-Fs por $10^{5}$ células plaqueadas. Isso significa que garrafas contendo menos de 10 CFU-Fs a partir de garrafas plaqueadas com $10^{5}$ células mononucleares indicam uma baixa eficiência na formação de colônias, garrafas contendo entre dez e cinqüenta colônias plaqueadas com $10^{5}$ células mononucleares indicam uma quantidade desejável, e aquelas que contêm uma formação de colônias num valor numérico acima de 50 colônias plaqueadas com $10^{5}$ células mononucleares indicam uma alta eficiência na formação de colônias.

Porém para determinarmos essa eficiência de formação de colônias em 
células plaqueadas da espécie em questão adaptamos a concentração previamente estipulada para o CFU-F que corresponde a $5 \times 10^{5}$ células, já que a partir dessa concentração há uma homogeneidade na formação das colônias.

\subsection{Ensaio para indução "in vitro" de diferenciação osteogênica e adipogênica}

As células foram mantidas em três placas de 24 wells, com cada poço contendo $2,5 \times 10^{4}$ células. Ao atingir $90 \%$ de confluência iniciou-se a indução da diferenciação com meio osteogênico em uma das três placas.

Esta indução foi feita em meio de cultura DMEM suplementado com $10 \%$ de Soro Fetal Bovino (SFB), 1\% de ciprofloxacina ${ }^{10}, 0,5 \mu \mathrm{M}$ ácido ascórbico ${ }^{11}, 10 \mathrm{mM}$ betaglicerofosfato $^{12}$ (BGP), e $10^{-6}$ de dexametazona ${ }^{13}$.

O meio era trocado a cada três dias e a diferenciação celular foi analisada após 21 dias em cultura através da coloração pelo alizarin red s.

Nos protocolos utilizados por Lu-Lu Lu et al (2006); Yu-Jen Chang et al (2005); Bieback et al (2004); Kazuhiro Sudo et al (2006) e Koch (2007), os suplementos empregados para indução da diferenciação adipogênica eram isobutilmetilxantina (IBMX), indometacin, dexametazona e insulina. Com o intuito de não onerar o experimento, tornando-o mais prático e objetivo, optou-se pelo uso do mesmo protocolo aplicado em estudos anteriores realizados por Huang et al (2007); Young et al (2001) e Balduíno et al (2008 - Informação verbal) que fazem o uso de

\footnotetext{
${ }^{10}$ Fresoflox, 2mg/mL, Fresenius Kabi Brasil Ltda, São Paulo.

${ }^{11}$ L- Ascorbic Acid, 100mg/mL, Lot 112k8307, Sigma Aldrich, St Louis, USA.

${ }^{12}$ Sigma-Aldrich, Madrid.

${ }^{13}$ Decadron, 2mg/ml, Aché Laboratórios Farmacêuticos, São Paulo.
} 
apenas dois dos suplementos: dexametazona e insulina ${ }^{14}$.

Para a indução da diferenciação adipogênica manteve-se as células de uma placa de cultura em DMEM suplementado com 10\% de SFB, $1 \%$ ciprofloxacina, $100 \mu \mathrm{g} / \mathrm{ml}$ insulina e $10^{-6}$ dexametazona. Na terceira placa, a dexametazona foi substituída pela hidrocortizona ${ }^{15}$ no meio de cultura. Os meios eram trocados a cada três dias e a diferenciação celular foi analisada após vinte e um dias em cultura através da coloração pelo oil Red o.

\footnotetext{
${ }^{14}$ Novolin R, Insulina Humana, 100UI/mL, Novo Nordis Paraná.

${ }^{15}$ Hemissuccinato de Hidrocortisona, 100mg/mL, Billi Farmacêutica Ltda, São Paulo
} 
Resultados 


\section{Resultados}

O objetivo do trabalho foi avaliar o comportamento das células progenitores mesenquimais provenientes do sangue de cordão umbilical de cães.

As células mesenquimais obtidas a partir do sangue de cordão umbilical apresentaram vantagens sobre as células obtidas da medula óssea por serem coletadas durante o nascimento, sem necessidade de sedação ou anestesia para seu procedimento, nem analgesia após a coleta. Não houve dano ao recém-nascido durante a obtenção do sangue.

\subsection{Obtenção de Células Mesenquimais do Sangue de Cordão Umbilical Canino}

A população de células obtidas do sangue de cordão umbilical canino era composta por duas populações identificadas pela capacidade de adesão ao plástico de cultivo. Conforme descrito em material e métodos, a população mononuclear total foi cultivada e após três dias de incubação, as células não-aderentes (hematopoéticas) foram removidas, enquanto que as células aderentes (mesenquimais) foram mantidas em meio fresco, renovado a cada quatro dias.

A população de células aderentes isoladas da porção mononuclear do sangue de cordão umbilical apresentou-se altamente heterogênea. Foram identificadas, pelo menos, quatro morfologias distintas: células epitelióides grandes (Figura 3A) e pequenas (Figura $3 \mathrm{C}$ ); células de aspecto fusiforme (Figura 3B); e células de aspecto estrelado (Figura 3D). Quando em confluência, as células apresentaram padrão de crescimento similar ao de miofibroblastos, com a tendência de formar estruturas semelhantes aos "vales e montanhas", normalmente observado em culturas de músculo liso e de estroma da medula óssea hematopoética. 

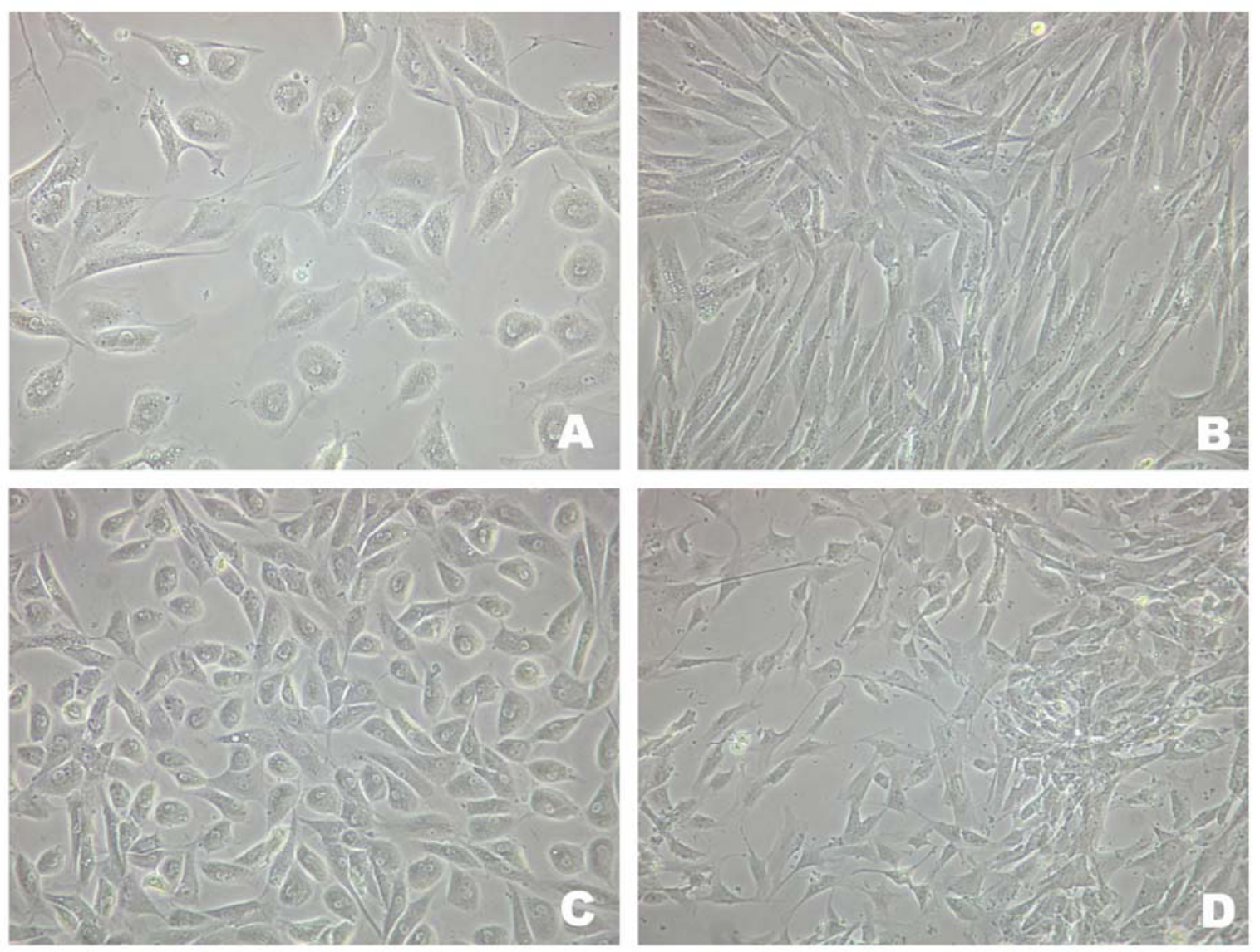

Figura 3 - Variação na morfologia das células após a formação de colônias em ensaio CFU-F, (do inglês Colony Forming Unit - Fibroblast) mantidas incubadas com $5 \%$ de $\mathrm{CO}_{2}$ a $37^{\circ} \mathrm{C}$ em meio DMEM, $10 \%$ de soro fetal bovino e antibiótico

4.2 Identificação e Quantificação de Progenitores Mesenquimais - CFU-F

O ensaio de quantificação da unidade formadora de colônias de fibroblasto (CFU-F, do inglês Colony Forming Unit - Fibroblast) é crítico na identificação do número de progenitores mesenquimais pluripotentes (FRIENDENSTEIN et al., 1967).

Conforme descrito anteriormente, as células mononucleares do sangue de cordão foram quantificadas e plaqueadas em três concentrações distintas, com o objetivo de avaliar o número ideal de células para a realização do ensaio. Utilizamos as concentrações de $2,5 \times 10^{5}, 5 \times 10^{5}$ e $10^{6}$ para cada frasco de cultivo com $25 \mathrm{~cm}^{2}$. $O$ ensaio foi realizado em triplicata. 
Após 13 dias de cultivo, os plaqueamentos com $2,5 \times 10^{5}, 5 \times 10^{5}$ e $10^{6}$ células mononucleares propiciou a formação de 20 colônias (de 14 a 28 colônias encontradas), 42 colônias (de 42 a 45 colônias formadas) e 83 colônias (de 80 a 91 colônias encontradas), respectivamente (Figura 4 A-I).

As três concentrações de células mononucleares utilizadas no presente ensaio foram adaptadas do protocolo proposto por Bianco (2008) quando se desejava analisar a eficiência da formação de colônias formadas a partir de células mononucleares plaqueadas em garrafas de $25 \mathrm{~cm}^{2}$ contendo $5 \mathrm{~mL}$ de meio de cultura. As colônias analisadas por ele eram provenientes da medula óssea humana.

Ademais, vale ressaltar que as colônias formadas a partir de $5 \times 10^{5}$ ou $10^{6}$ células mononucleares apresentaram-se mais heterogêneas quanto ao diâmetro (Figuras 4 D-F; 4 G-I) quando comparadas com àquelas formadas a partir de 2,5 $\mathrm{x}$ $10^{5}$ (Figura 4 A-C) conforme Gráfico 1. Com base neste dado, sugere-se a não utilização de um número menor que $5 \times 10^{5}$ células nos ensaios de CFU-F futuros.

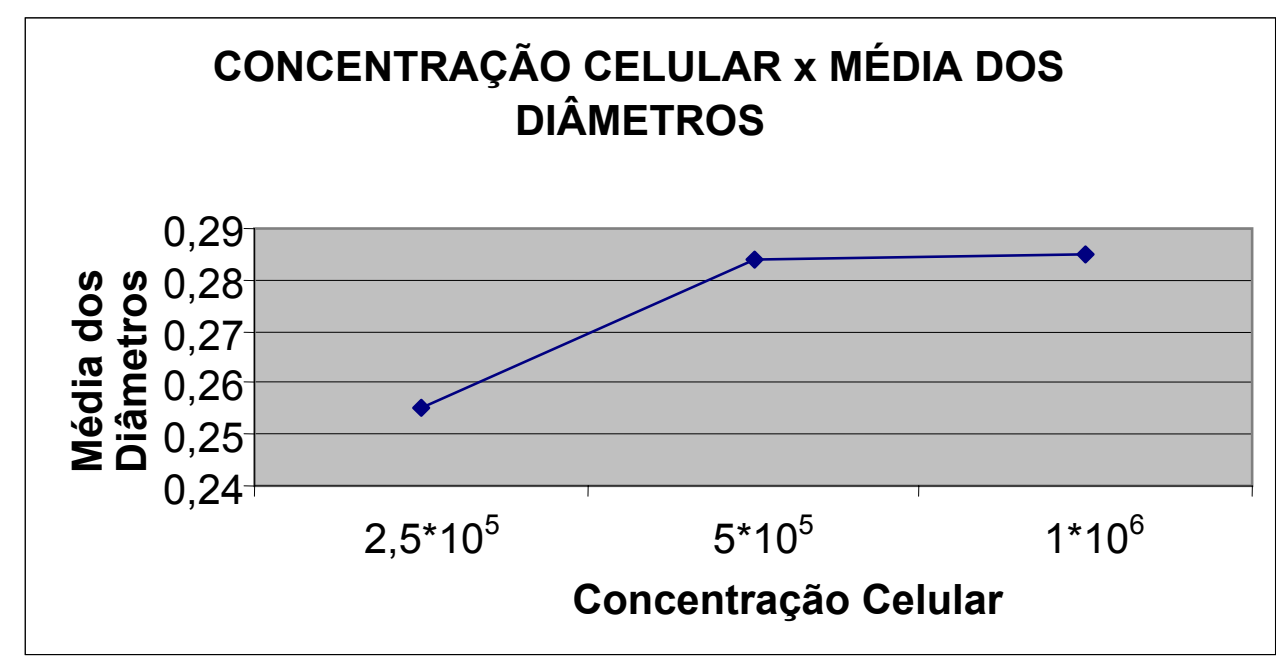

Gráfico 1 - Demonstração da homogeneidade nos diâmetros de uma mesma amostra para diferentes concentrações celulares plaqueadas 

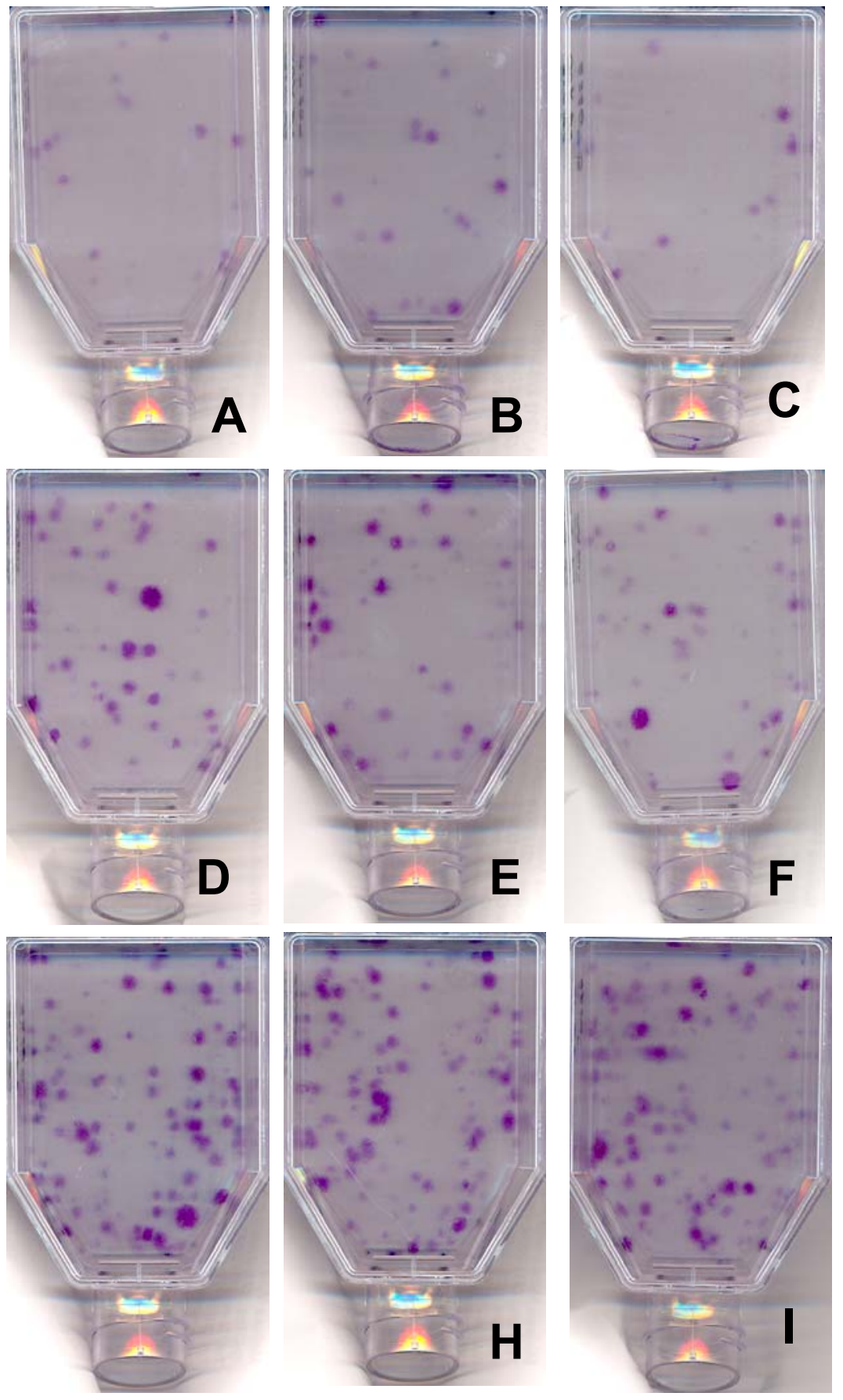

Figura 4 - A-C - Formação de colônias em garrafas plaqueadas com $2,5 \times 10^{5}$ células mononucleares após ensaio CFU-F;

D-F - Formação de colônias em garrafas plaqueadas com $5 \times 10^{5}$ células mononucleares após ensaio CFU-F; G-I- Formação de colônias em garrafas plaqueadas com $10^{6}$ células mononucleares após ensaio CFU-F

Observação: todos os frascos foram corados com cristal violeta. 
As células de uma nova alíquota foram plaqueadas na concentração $5 \times 10^{5}$ sugerida anteriormente, para uma melhor visualização e heterogeneicidade dessas colônias. Dessa alíquota obteve-se a formação de 158 colônias (152 a 164), e uma diferença morfológica nas colônias coradas. (Figura 5 A-B).
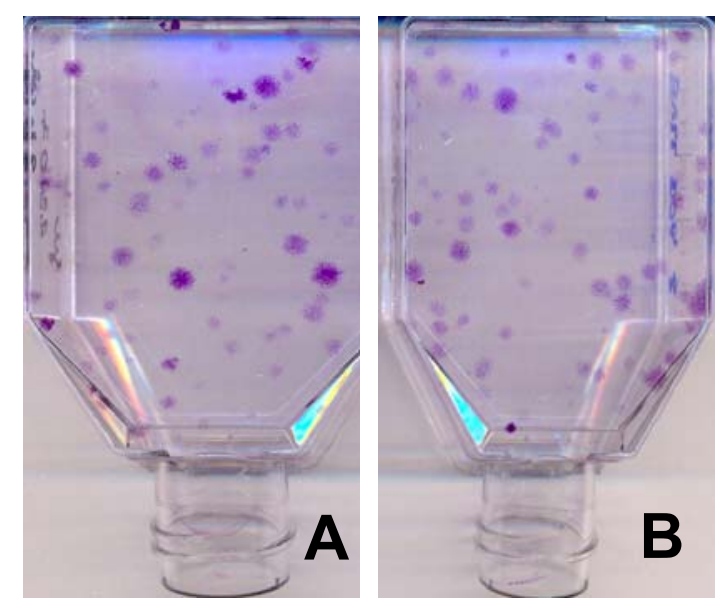

Figura 5 A-B- Formação de colônias nas garrafas plaqueadas em duplicata da segunda alíquota de sangue contendo $5 \times 10^{5}$ células mononucleares após ensaio CFU - F e coradas com cristal violeta

Uma nova alíquota de sangue foi coletada, as células mononucleares separadas e plaqueadas na concentração supracitada. Em amostras de uma mesma ninhada, foram encontradas colônias com morfologia semelhantes entre si, porém diferente das colônias formadas a partir de alíquotas anteriores. Essas colônias apresentaram uma maior quantidade de colônias com um diâmetro superior a $0,5 \mathrm{~cm}$ (Figura $6 \mathrm{~A}-\mathrm{E})$. 


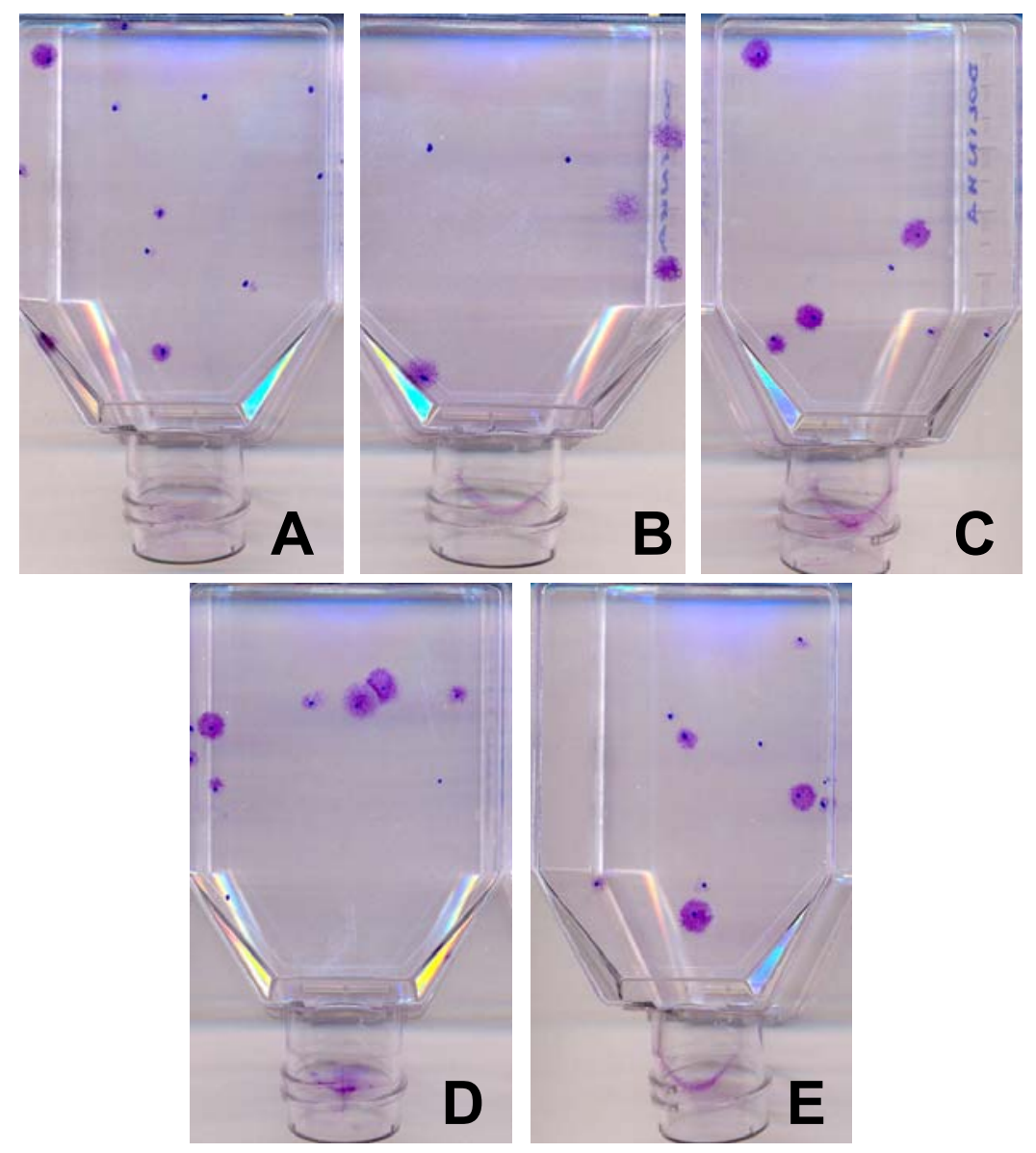

Figura 6 A-E- Formação de colônias em garrafas plaqueadas em cinco amostras da terceira alíquota de sangue contendo $5 \times 10^{5}$ células mononucleares após ensaio CFU - $\mathrm{F}$ e coradas com cristal violeta.

Numa outra alíquota foram coletadas três amostras, essas amostras foram processadas em duplicata para ensaio de CFU-F, e em apenas uma pode-se observar pequenas colônias com diâmetro inferior a $0,3 \mathrm{~cm}$ e um valor numérico de 20 e $11(15,5)$ colônias respectivamente (Figura 7). 


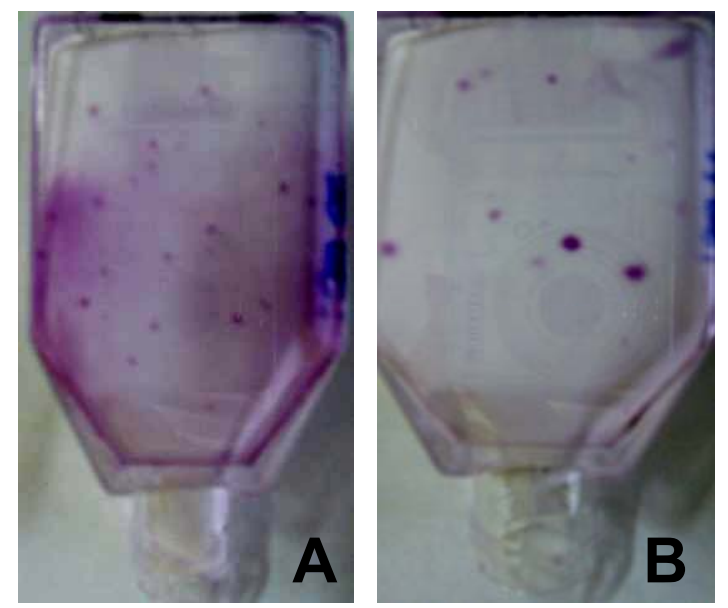

Figura 7 A-B- Formação de colônias em garrafas plaqueadas em duas amostras da quarta alíquota de sangue contendo $5 \times 10^{5}$ células mononucleares após ensaio CFU-F e coradas com cristal violeta

\subsection{Análise dos Diâmetros das Colônias Formadas}

Após a contagem do número total de colônias formadas, aferiu-se aleatoriamente o diâmetro de $30 \%$ destas colônias, e foi observada uma variação nos valores numéricos encontrados conforme tabela a seguir:

Tabela 1 - Relação da média do número de colônia formado versus média dos diâmetros do total de amostras

\begin{tabular}{|c|c|c|}
\hline Número da amostra & $\begin{array}{c}\text { Média do número de } \\
\text { colônia formado }\end{array}$ & $\begin{array}{c}\text { Média dos diâmetros do total de } \\
\text { amostras }\end{array}$ \\
\hline 1 & 41,26 & 0,274 \\
\hline 2 & 79 & 0,27 \\
\hline 3 & 9,2 & 0,41 \\
\hline 4 & 15,5 & 0,141 \\
\hline
\end{tabular}


A tabela mostrou que o número de colônias formado não está relacionado com o diâmetro dessas colônias. O mesmo dado é comprovado quando comparamos algumas alíquotas das quatro amostras coletadas conforme Figura 8 A-D.

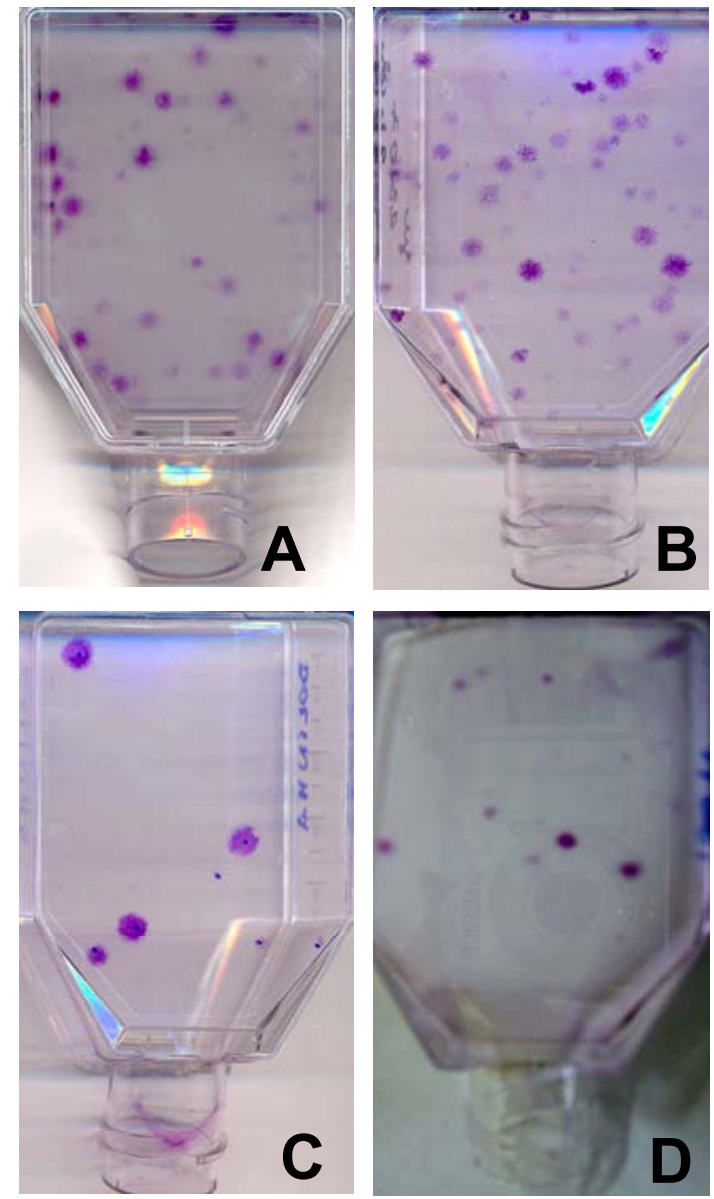

Figura 8 A-D - Comparação entre uma alíquota de cada amostra utilizada para quantificação celular através de CFU-F, todas plaqueadas com $5 \times 10^{5}$ células e coradas com cristal violeta. Demonstrando uma diferença no diâmetro das colônias formadas sugerindo uma variação entre os indivíduos

Assim como os tipos de colônias observadas foram distintos, os tipos de células que compõem as colônias também se apresentaram distintos. Similar aos dados descritos anteriormente, foi identificado, quatro morfologias distintas: células 
epitelióides grandes (Figura 9A) e pequenas (Figura 9C); células de aspecto fusiforme (Figura 9B); e células de aspecto estrelado (Figura 9D).

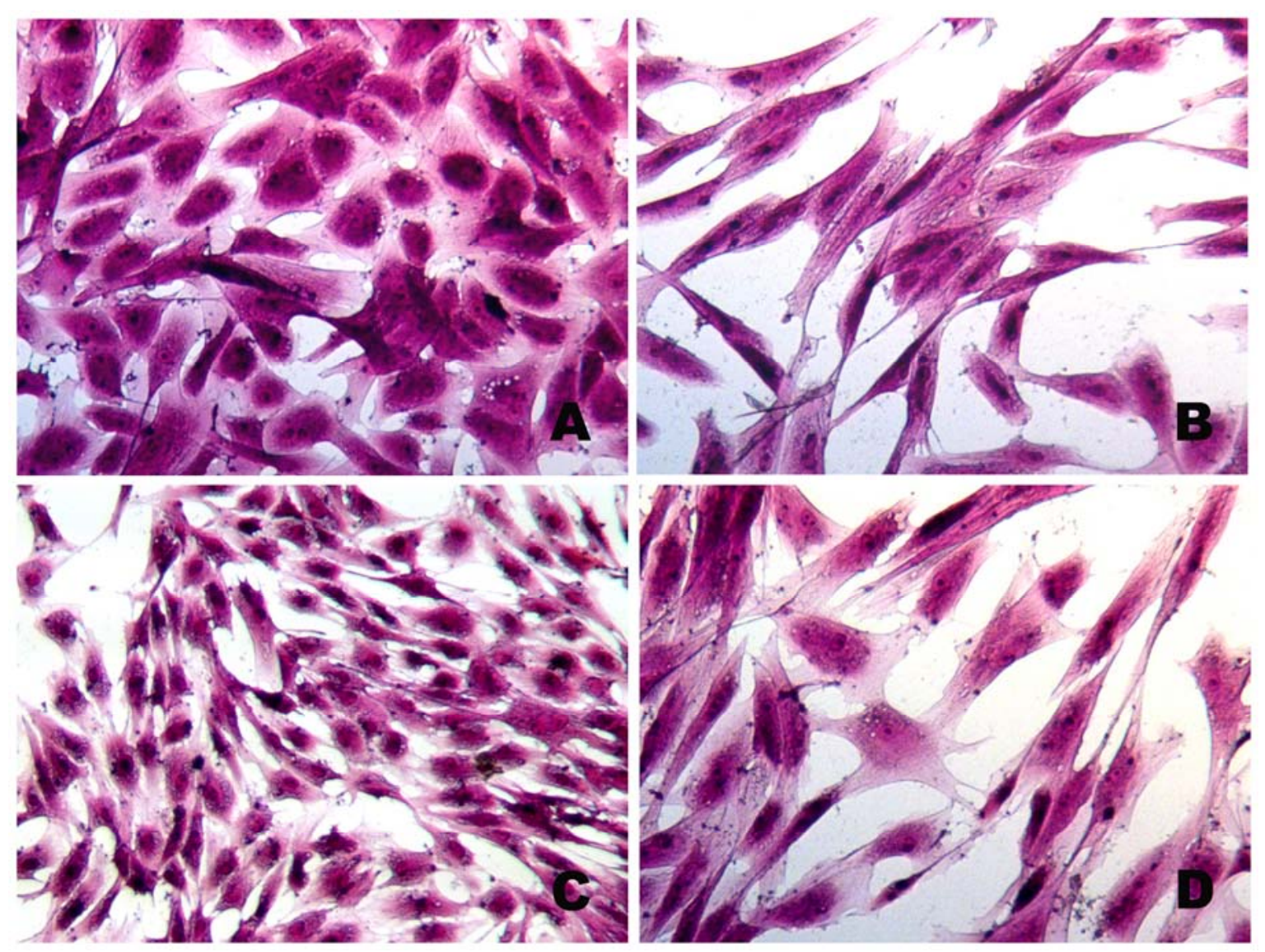

Figura 9- Variação na morfologia das células após a formação de colônias em ensaio CFU-F, (do inglês Colony Forming Unit - Fibroblast) e coradas com cristal violeta

Vale ressaltar que dentro de uma única colônia, apenas um tipo morfológico foi observado, sugerindo clonalidade. Ademais, as colônias com maior diâmetro (superior a 0,5cm) e mais compactas apresentavam células de morfologia epitelióide grande, conforme observado na Figura 9A. Por outro lado, as colônias de diâmetro médio $(0,5$ a $0,3 \mathrm{~cm})$ e pequeno (inferior a $0,3 \mathrm{~cm}$ ), eram compostas preferencialmente por células estreladas e fusiformes, respectivamente (Figuras 9B e 9C).

Destaca-se também que, quanto maior o diâmetro das colônias, maior a sobreposição celular. Logo podemos afirmar que um maior número de células era 
formado à partir de uma única célula progenitora, e que quanto menos diferenciada essa célula, maior a sua capacidade de gerar "clones".

Tabela 2- Tabela demonstrando as informações sobre cada fêmea gestante utilizada no experimento e o número de colônias formadas a partir de um milhão de células mononucleares plaqueadas

Tabela de CFU-Fs - Sangue de Cordão Umbilical Canino

\begin{tabular}{c|c|c|c|c|c}
\hline $\begin{array}{c}N^{\circ} \\
\text { Coleta }\end{array}$ & Raça & $\begin{array}{c}\text { Peso das } \\
\text { Fêmeas }\end{array}$ & $\begin{array}{c}N^{\circ} \\
\text { filhotes }\end{array}$ & $\begin{array}{c}\text { Volume } \\
\text { Coletado }\end{array}$ & $\begin{array}{c}N^{\circ} \\
\text { colônias/milhão } \\
\text { de células }\end{array}$ \\
\hline 1 & $\begin{array}{l}\text { Bulldog } \\
\text { Inglês }\end{array}$ & $35 \mathrm{Kg}$ & 2 & $8 \mathrm{~mL}$ & $\begin{array}{r}56-112-7284- \\
90-78 \\
80-91-78 \\
(82,33)\end{array}$ \\
\hline 2 & $\begin{array}{l}\text { Bulldog } \\
\text { Inglês }\end{array}$ & $26 \mathrm{Kg}$ & 5 & $2,5 \mathrm{~mL}$ & $152-164(158)$ \\
\hline 3 & Pug & $15 \mathrm{Kg}$ & 5 & $7 \mathrm{~mL}$ & $24(18)$ \\
\hline 4 & Boxer & $25 \mathrm{Kg}$ & 6 & $3 \mathrm{~mL}$ & $4022(31)$ \\
\hline
\end{tabular}


4.4 Avaliação da Eficiência de Formação de Colônias (CFE)

Tabela 3- Eficiência na formação de colônias à partir de $5 \times 10^{5}$ células mononucleares plaqueadas

\begin{tabular}{c|c|c} 
AMOSTRA & $\begin{array}{c}\text { No DE COLÔNIAS FORMADAS/ 5X10 } \\
\text { CÉLULAS MONONUCLEARES PLAQUEADAS }\end{array}$ & $\begin{array}{c}\text { EFICIÊNCIA NA } \\
\text { FORMAÇÃO DE } \\
\text { COLÔNIAS }\end{array}$ \\
\hline 1 & 41,16 & DESEJÁVEL \\
\hline 2 & 79 & ALTA \\
\hline 3 & 9 & BAIXA \\
\hline 4 & 15,5 & DESEJÁVEL
\end{tabular}

Foi considerada também a eficiência da formação de colônias em cada amostra. Essa análise foi adaptada à partir da avaliação sugerida por Bianco (2008). O número de colônias formadas foi avaliado a partir de $5 \times 10^{5}$ células mononucleares plaqueadas.

Garrafas contendo menos de dez colônias a partir de $5 \times 10^{5}$ células mononucleares plaqueadas indicam uma baixa eficiência na formação de colônias. Garrafas contendo entre dez e cinqüenta colônias indicam uma quantidade desejável, e aquelas células que formaram colônias num valor numérico acima de 50 também plaqueadas na concentração de $5 \times 10^{5}$ células mononucleares indicam uma alta eficiência na formação de colônias (BIANCO, 2008).

Das quatro amostras analisadas, apenas uma apresentou baixa eficiência, duas apresentaram uma eficiência desejável, e finalmente uma apresentou alta eficiência. 


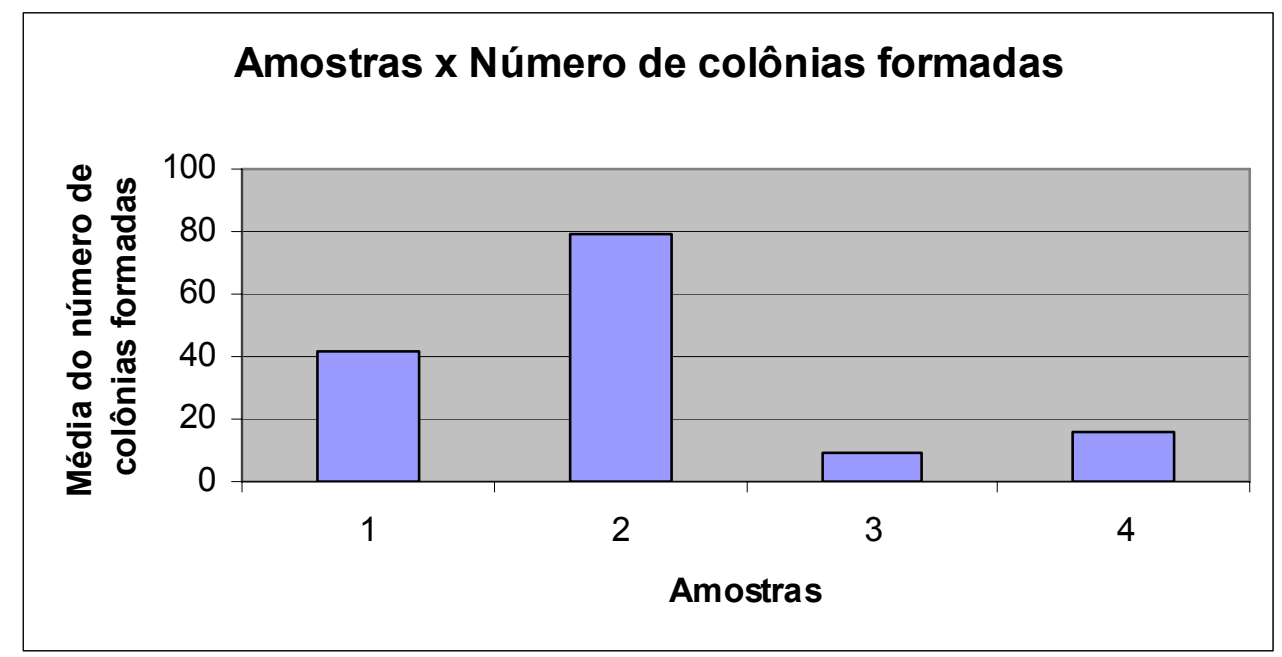

Gráfico 2- Relação da média do número de colônias formadas de acordo com as amostras

As amostras 1 e 4 apresentaram um número desejável de colônias formadas enquanto a amostra número 3 não atingiu o valor desejável e a amostra número 2 apresentou alta eficiência na formação de colônias.

\subsection{Ensaio para Indução "in vitro" de Diferenciação Osteogênica e Adipogênica}

Para analisar o potencial de indução de diferenciação das células mesenquimais obtidas do sangue de cordão umbilical, plaqueamos $2,5 \times 10^{4}$ por poço de uma placa de 24 poços, e incubamos em DMEM 10\% de soro fetal bovino (SFB), $1 \%$ de ciprofloxacina, na presença de $10 \mathrm{mM}$ betaglicerofosfato (BGP), 0,5 $\mu \mathrm{M}$ ácido ascórbico e $10^{-6}$ de dexametazona para indução osteogênica e $10^{-6}$ de dexametazona e $100 \mu \mathrm{g} / \mathrm{mL}$ de insulina, para a indução adipogênica.

Com essa metodologia empregada, não obtivemos resultados satisfatórios, as células não apresentaram a marcação desejada através das colorações alizarin red $s$ e oil red o utilizadas para visualização das culturas celulares induzidas para 
osteogêse e adipogênese respectivamente. 
57

Discussão 


\section{DISCUSSÃO}

O objetivo do trabalho foi avaliar o comportamento das células progenitores mesenquimais provenientes do sangue de cordão umbilical de cães.

As células mesenquimais obtidas do sangue de cordão umbilical apresentaram vantagens sobre as células mesenquimais obtidas da medula óssea por serem coletadas durante o nascimento, sem a necessidade de sedação ou anestesia para seu procedimento, nem analgesia após a coleta. Não houve dano ao recém-nascido durante a obtenção do sangue, conforme descrito por alguns autores (RUBSTEIN et al., 1995; KII-SOO PARK et al., 2006; LU-LU LU et al., 2006).

Essas células também apresentaram-se imaturas pois formaram colônias à partir de uma única célula progenitora e poderiam ser utilizadas como uma fonte para transplantes autólogos assim também descrito por Kii-Soo Park et al em 2006 e por Lu-Lu Lu et al no mesmo ano.

Para coletas do sangue de cordão umbilical humano Chivu et al. (2002), Bieback et al. (2006), Chang et al. (2006), Ki-Soo Park (2006) utilizaram bolsas contendo o anticoagulante CPD do inglês citrate phosphate dextrose-adenine. No presente trabalho, assim como protocolo utilizado por Fuchs et al. (2007) para coleta do sangue de cordão umbilical de ovinos e por Jin-Fu Wang et al. (2004) para coleta de sangue de cordão umbilical humano, o anticoagulante de escolha foi a heparina sódica. Com a utilização deste anticoagulante obtivemos sucesso na separação celular por gradiente de densidade e preservação da viabilidade celular.

Após uma centrifugação com 0 reagente FICOLL as células nucleadas formaram um "anel" na interface, esse "anel" foi retirado e após a centrifugação formou um pellet contendo células mononucleares e algumas hemácias. Igualmente ocorreu em experimento realizado por Al-Lebban, 1987; Neuner, 1998; Guzman, 
2002; Bieback, 2004; Jin-Fu Wang, 2004; Lu-Lu Lu, 2006 e Kii-Soo Park, 2006.

Assim como metodologia utilizada por Lu-Lu Lu (2006), as células mesenquimais foram isoladas da população total de células mononucleadas através da adesão ao plástico de cultivo. Após três dias de cultivo as células que permaneciam no sobrenadante, ou seja, aquelas não aderentes ao plástico eram retiradas e as garrafas lavadas, restando apenas as células mesenquimais. Enquanto Bieback (2004) removia as células não aderentes somente no sétimo dia de cultivo.

A partir desse plaqueamento observamos a formação de colônias o que indica a presença de células precursoras capazes de gerar "clones".

Yu-Jen Chang et al. (2006) asseguraram que tanto as colônias contendo células mesenquimais provenientes do sangue de cordão umbilical quanto as provenientes da medula óssea de humanos apresentaram-se com células de homogênea morfologia fibroblast-like (formato fibroblastóide). Como já citado no presente estudo. Em meio às colônias de células mesenquimais proveniente apenas do sangue de cordão umbilical canino, foi encontrada uma variação morfológica entre as células de uma mesma colônia.

Analisamos a capacidade dessas células progenitoras em formar colônias. $\mathrm{O}$ ensaio de quantificação da unidade formadora de colônias de fibroblasto (CFU-F, do inglês Colony Forming Unit - Fibroblast) é decisivo na identificação do número de progenitores mesenquimais pluripotentes (FRIENDENSTEIN et al., 1967).

Plaqueamos as células mononucleares em três concentações distintas. Essas três concentrações de células mononucleares utilizadas no presente ensaio foram adaptadas do protocolo proposto por Bianco (2008) quando se desejava analisar a eficiência da formação de colônias formadas a partir de células mononucleares 
plaqueadas em garrafas de $25 \mathrm{~cm}^{2}$ contendo $5 \mathrm{~mL}$ de meio de cultura. As colônias analisadas por ele eram provenientes da medula óssea humana.

Apenas as colônias contendo 50 células ou mais foram contadas conforme fez Lu-Lu lu (2006).

Para o ensaio de quantificação de unidades formadoras de colônia de fibroblasto - CFUF em humanos foram utilizados por Lu-Lu Lu et al. (2006), células de duas fontes distintas: sangue de cordão umbilical e medula óssea. Essas células foram isoladas e plaqueadas em diferentes concentrações de células/poço. As células mononucleares obtidas do sangue de cordão umbilical foram plaqueadas nas concentrações $10^{5}, 10^{4}, 2.5 \times 10^{4}, 1.25 \times 10^{4}, 6.25 \times 10^{3}, 3.125 \times 10^{3}$ enquanto as obtidas da medula óssea foram plaqueadas nas concentrações de $2 \times 10^{6}, 10^{6}$, $5 \times 10^{5}, 2.5 \times 10^{5}, 1.25 \times 10^{5}, 6.25 \times 10^{4}$.

Obtendo um resultado numérico significativamente alto no sangue de cordão

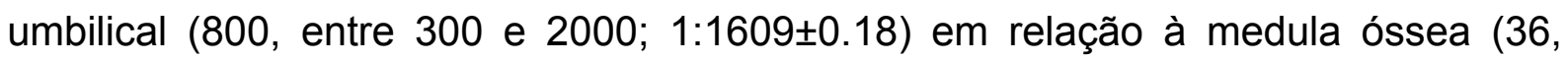
entre 16 e $64 ; 1: 35700 \pm 0.01)$. Os resultados encontrados por esse autor no ensaio CFU-F à partir da medula óssea humana (44,9 variando entre 2 e 79 colônias encontradas), correspondem aos resultados encontrados à partir do ensaio de CFUF do presente estudo.

Num ensaio realizado por Jin-Fun Wang et al. (2004), a freqüência de

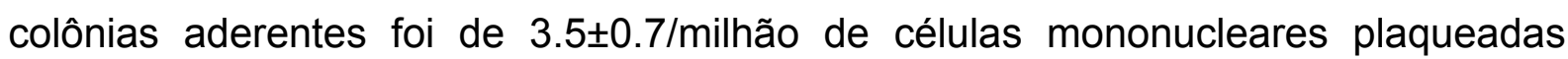
utilizando meio IMEM suplementado com $20 \%$ de soro fetal bovino.

Em contrapartida, Yu-Jen Chang et al. (2006) afirmaram que um milhão de células mononucleares plaqueadas a partir do sangue de cordão umbilical humano apresentaram um décimo da freqüência de CFU-F encontrada na medula óssea plaqueada com a mesma concentração celular. 
O presente estudo considera também a eficiência da formação de colônias em cada amostra. Essa análise é adaptada a partir da avaliação sugerida por Bianco (2008). O número de colônias formadas foi avaliado a partir de $5 \times 10^{5}$ células mononucleares plaqueadas.

Garrafas contendo menos de dez colônias a partir de $5 \times 10^{5}$ células mononucleares plaqueadas indicam uma baixa eficiência na formação de colônias. Garrafas contendo entre dez e cinqüenta colônias indicam uma quantidade desejável, e aquelas células que formaram colônias num valor numérico acima de 50 também plaqueadas na concentração de $5 \times 10^{5}$ células mononucleares indicam uma alta eficiência na formação de colônias (BIANCO, 2008).

No estudo realizado por Mankani et al. (2006) células mononucleares da medula óssea de quatro cães foram plaqueadas e as colônias formadas a partir de células mesenquimais aderidas ao plástico de cultivo foram coradas com metilvioleta, obtendo um resultado de $81,5( \pm 12.6)$ colônias por $10^{5}$ células plaqueadas. Demonstrando uma alta eficiência na formação de colônias, enquanto em nosso experimento ressaltamos uma variação entre baixa e alta eficiência na formação de colônias.

Posteriormente a essas avaliações, submetemos as células plaqueadas ao ensaio de indução às diferenciações osteogênica e adipogênica.

Bieback et al. (2004), utilizaram placas de seis wells, contendo $3,1 \times 10^{3}$ células por $\mathrm{cm}^{2}$, essa células eram provenientes da medula óssea humana, expandiram essas células até $80 \%$ de confluência no poço onde então, iniciaram a indução osteogênica com $0,1 \mu \mathrm{M}$ de dexametazona, uma concentração menor de ácido ascórbico 0,05 mM e as mesmas concentrações de betaglicerofosfato e soro fetal bovino utilizadas em nosso experimento. Os pesquisadores analisaram as 
células após três semanas de indução, estas apresentaram uma aumento da atividade da fosfatase alcalina bem como um aumento da mineralização, marcada pelo método de von kossa.

Além dessa, os pesquisadores utilizaram células da mesma fonte para indução da adipogênese em meio contendo $1 \mu \mathrm{M}$ dexametazona, 0,5 mM IBMX, $10 \mu \mathrm{g} / \mathrm{mL}$ insulina e $0,2 \mathrm{~mm}$ de indomethacin, que apresentaram marcação pelo oil red 0.

Kumar et al. (2007) obteve células mononucleares do sangue de cordão umbilical de suínos, plaqueou $2 \times 10^{5}$ células/placa de $35 \mathrm{~mm}$, em meio de cultura ADMEM (advanced DMEM) para expansão celular, e na indução das células à diferenciação osteogênica usou as mesmas concentrações dos reagentes utilizados por Bieback et al. (2004). Ao final de 12 dias de indução as células apresentaram aumento da atividade da fosfatase alcalina, e a formação de matriz mineralizada pôde ser observada com os marcadores Von Kossa e alizarin red s.

Sudo et al. (2007) utilizou membranas amnióticas humanas como fonte de fibroblastos. Colagenase, tripsina, solução de EDTA em meio de cultura aMEM foram usadas para o isolamento. Após o isolamento e confluência de $100 \%$, os fibroblastos foram induzidos à diferenciação osteogênica com o meio de cultura DMEM-HG (High glucose), e as mesmas concentrações de soro fetal bovino, betaglicerofosfato, dexametazona e ácido ascórbico utilizadas em nosso experimento. O autor relata ainda que uma variedade de células progenitoras podem diferenciar em células osteogênicas, exceto as células do cordão umbilical.

Nesse mesmo experimento o autor obteve outra amostra de células para indução da adipogênese mantendo essa células inicialmente em meio suplementado com DMEM-HG, $10 \%$ de SFB e $10 \mu \mathrm{g} / \mathrm{mL}$ de insulina apenas. Passada uma semana 
o meio foi acrescido de $0,2 \mathrm{mM}$ indomethacin, $1 \mu \mathrm{M}$ dexametazona, 0,5 mM IBMX, trocado a cada quatro dias e a cultura foi mantida por 24 a 30 dias. Após analise com oil red o o autor relata que células progenitoras podem diferenciar em adipocitos, menos as células extraídas da membrana amniótica.

Huang et al. (2007) assim como no presente estudo, optaram pela utilização de apenas dois suplementos no meio de cultivo para indução adipogênica, são eles a dexametazona e a insulina.

Huang et al. (2007) utilizaram $10 \mathrm{ng} / \mathrm{mL}$ de insulina e $10^{-7}$ dexametazona por três semanas, para indução de células extraídas do tecido subcutâneo na região facial de suínos jovens. Quando analisadas, essas células apresentaram vacúolos lipídicos, positivas para marcação oil red o.

Porém, Kon et al. (2000) relatam que as células obtidas da medula óssea de ovelhas independem da indução com dexametazona e não expressam a atividade da fosfatase alcalina, sugerem que sejam realizados estudos futuros para uma análise do contexto biológico geral dessas células

Com a metodologia empregada, e as concentrações das substâncias utilizadas em nossa tentativa, não obtivemos resultados satisfatórios. As células não apresentaram a marcação desejada através das colorações alizarin red s e oil red o utilizadas para visualização das culturas celulares induzidas para osteogêse e adipogênese. 
Conclusão 


\section{CONCLUSÃO}

1- As células mononucleares obtidas do sangue de cordão umbilical canino possuem uma "subpopulação" passível de isolamento através da aderência ao plástico de cultivo.

2- As células aderentes isoladas da população de células mononucleares provenientes do sangue do cordão umbilical na espécie canina são passíveis de quantificação através do ensaio de CFU-F havendo uma variação individual entre uma mesma espécie.

3- Essa variação pode ocorrer também entre as raças analisadas.

4- As células analisadas apresentam comportamento de células mesenquimais presentes na medula óssea hematopoética humana.

5- Possivelmente estabelecendo as concentrações ideais de substâncias, essas células serão passíveis de indução à diferenciação adipogênica e osteogênica assim como ocorre com as células mesenquimais da medula óssea hematopoética humana. 
Considerações Finais 


\section{CONSIDERAÇÕES FINAIS}

Esperamos que as células da espécie em questão não tenham o comportamento de células mesenquimais provenientes da medula óssea de ovelhas como descrito por Kon et al, 2000.

Pré supondo que na medula óssea hematopoética, no sangue de cordão umbilical humano, e no sangue do cordão umbilical canino existam populações celulares semelhantes, ou seja, com o mesmo comportamento, as células mesenquimais provenientes do sangue de cordão umbilical canino seriam passíveis de indução à diferenciação osteogênica e adipogênica.

Empenhamos-nos para que essa indução da diferenciação fosse alcançada, porém a Fundação de Amparo à Pesquisa do Estado de São Paulo não nos permitiu prorrogar o prazo de entrega do relatório final. Cumprimos parte do que havíamos proposto, entretanto para uma futura publicação de qualidade será necessário que esta indução à diferenciação seja realizada. 
Referências 


\section{REFERÊNCIAS}

ALBERTS, B.; JOHNSON, A.; LEWIS, J.; RAFF, M.; ROBERTS, K.; WALTER, P.; Biologia molecular da célula. 4.ed. Ed Artmed, Brasil, 2004.

ALMEIDA J. M.; SANTOS, R. M. B.; MIGLINO M. A.; MORAIS-PINTO, L. Morphology of the "funiculus umbilicalis" in wooless mongrel sheep (Ovis aries, $L$. 1758) Braz. J. Vet. Res. Anim. Sci. v. 37, n. 3, p. 348-354, 2000.

AL-LEBBAN, Z. S.; LANGE, R. D.; JONES, J. B.; LOTHROP, C. D. Long-term bone marrow culture systems: normal and cyclic hematopoietic dogs. Can. J. Vet. Res., v. 51, p. 162-168, 1987.

BALDUÍNO, A. Análise celular e molecular do componente estromal da região subendosteal da medula óssea: o nicho das células-tronco hematopoéticas. 2006. 27 f. Tese (Doutorado em Ciências Morfológicas) Pós -Graduação em Ciências Morfológicas - Universidade Federal do Rio de Janeiro, Rio de Janeiro, 2006.

BARKER, J. N.; WAGNER, J. N., Umbilical cord blood transplantation: current practice and future innovations. Crit. Rev. Oncol. Hematol. v. 48, n. 1, p. 35-43, 2003.

BIANCO, P.; KUZNETSOV, S. A.; RIMINUCCI, M.; ROBEY, P. G. Section II Mesoderm - 6 Postnatal Skeletal Stem Cells p. 117-148, 2008 Disponível em: <http://www.ucm.es/BUCM/compludoc/W/10701/00766879_3.htm> Acesso em 14 abr 2008.

BIANCO, P.; RIMUNUCCI, M.; GRONTHOS, S.; ROBEY, P. G. Bone Marrow Stromal Stem Cells: Nature, Biology and Potential Applications. Stem Cells v. 19, p. 180-192, 2001.

BIEBACK, K.; SUSANNE, K.; KLUTER, H.; EICHLER, H. Critical paramenters for the isolation of mesenchymal stem cells from umbilical cord blood. Stem cells, v. 22, p. $625-634,2004$.

BITTENCOURT R. A. C.; PEREIRA, H. R.; FELISBINO, S. L.; MURADOR, P.; OLIVEIRA, A. P. E.; DEFFUNE E. Isolamento de células-tronco mesenquimais da medula óssea. Acta Ortop Brás. v.14, n.1, p.22-24, 2006.

BROXMEYER, H. E.; GLUCKMAN, E.; AUERBACH, A.; DOUGLAS, G. W.; FRIEDMAN, H.; COOPER, S.; HANGOC, G.; KUTZBERG, J.; BARD, J.; BOYSE, E. 
E. Human umbilical cord blood: aclinically useful source of transplantable hematopoietic stem/progenitor cells. Int J Cell Cloning. v.1, p.76-91, 1990. Supplement 1.

CAMARGO, F. D.; CHAMBERS, S. M.; GOODELL, M. A. Stem Cell plasticity: from transdifferentiation to macrophage fusion. Cell Prolif. v. 37, p. 55-65, 2004.

CARVALHO, F. S. R.; MIGLINO, M. A.; SEVERINO R. S.; FERREIRA F. A.; FERREIRA C. G.; SANTOS T. C. Microscopic features of the umbilical cord in equine (Equus caballus 3/4 Linnaeus, 1758) Braz. J. Vet. Res. Anim. Sci. v. 38, n. 2 p. 6668, 2001.

CHIRSTENSEN J. L.; WEISSMAN, I. L. Flk-2 is a marker in hematopoietic stem cells differentiation: A simple method to isolate long-term stem cells. PNAS V $98 \mathrm{~N} 25$, 2001.

CHIVU, M.; DIACONU, C. C.; BRASOVEANU, L.; ALEXIU, I.; BLEOTU, C.; BANCEANU, G.; MISCALENCU, D.; CERNESCU, C. Ex vivo differentiation of umbilical cord blood progenitor cells in the presence of placental conditioned médium. J. cell Mol. Med. v. 6, n. 4, p. 609-620, 2002.

DEL CARLO, R. J., Células-tronco: células da esperança. Revista do Conselho Federal de Medicina Veterinária, Suplemento Técnico, p.60-68, 2005.

DEXTER, T. M.; ALLEN, T. D.; LAJTHA, L. G. Conditions controlling the proliferation ofhematopoetic stem cells in vitro. J.Cell Physiol, v. 91, p. 335, 1977.

FRESHEY, R. I. Culture of animal cells: a manual of Basic Technique. 4. ed. New York: Wiley-Liss,1994.

FRIEDENSTEIN, A. J.; PIATETZKY, S. I.; PETRAKOVA, K. V. Osteogenesis in transplants of bone marrow cells. J. Embryol. Exp. Morphol, v. 16, p. 381-390,1966. 
FRIEDENSTEIN, A. Y.; LALYKINA, K. S.; TOLMACHEVA, A. A. Osteogenic activity of peritoneal fluid cells induced by transitional epithelium. Acta Anat, v. 68, n. 4, p.532-549, 1967.

FRIEDENSTEIN, A. J.;PETRAKOVA K. V.; KUROLESOVA A. I.; FROLOVA G. P. Heterotopic of bone marrow. Analysis of precursor cells for osteogenic and hematopoetic tissues. Transplantation, v. 6, n. 2, p. 230-47,1968.

FUCHS, J. R.; HANNOUCHE, D.; TERADA, S.; ZAND, S.; VACANTI, J. P.; FAUZA, D. O.; Cartilage enginnering from ovine umbilical cord blood mesenchymal progenitor cells. Stem cells, v. 23, p. 958-964, 2007.

GANG, E. J.; JEONG, J. A.; HONG, S. H.; HWANG, S. H.; KIM, S. W.; YANG, I. H.; AHN, C.; HAN, H.; KIM, H. Skeletal myogenic differentiation of mesenchymal stem cells isolated from human umbilical cord blood. Stem cells, v. 22, p. 617-624, 2004.

GARCIA NAVARRO, C. E. K. Manual de hematologia veterinária, 2.ed. Ed. Varella. São Paulo, 2005.

GREEN, A. E.; ATHREYA, B.; LEHR H. B.; CORRIEL, L. L.; Viability of cell culture following extended preservation in liquid nitogen. Proc. Soc. Exp. Biol. Med, v. 124, p. 1302-1307, 1967.

GROTTO, H. Z. W.; NORONHA, J. F. A. Identificação de células-tronco hematopoéticas: citometria de fluxo convencional versus contador hematológico automatizado. Rev. Bras. Hematol. e Hemotr, v. 25, n. 3, p. 169-172, 2003.

GUZMAN, P. F.; RODRIGUEZ, G.; MAYANI, H. In Vitro differentiation of a CD34 Cell-Enriched Hematopoietic cell population from human umbilical cord blood in response to recombinant cytokines. Arch. of Medical Research, v.33 p. 107-114, 2002.

HERZOG, E. L.; CHAI, I.; KRAUSE, D. S. Plasticity of marrow-derived stem cells. Blood, v.102, n. 10, p. 3483-3493, 2003.

HUANG, T.; HE, D.; KLEINER, G.; KULUZ, J.; Neuron-like Differentiation of Adipose Derived Stem Cells from Infant Piglets in Vitro. The J. of Spinal Cord Med, v. 30, p. 35-40, 2007. Supllement 1

JIN-FU WANG; LI-JUAN WANG; YI-FAN WU; YING-XIANG; CHUN-GANG XIE; BING-BING JIA; HARRINGTON, J.; MC NIECE, I. K. Mesenchymal stem/progenitor cell in human umbilical cord blood as support for ex vivo expansion of CD34 ${ }^{+}$ 
hematopoietic stem cells and for chondrogenic differentiation. Haematologica Stem cell Transplantation, v. 89 n. 7, 2004.

JUNQUEIRA, L. C.; CARNEIRO, J. Histologia Básica, 7 ed, Rio de Janeiro: editora Guanabara Koogan, 1999, cap. 13, p. 188-199.

KACEMI, A.; CHALLIER, J. C.; GALTIER, M.; OLIVE, G. Culture of endothelial cells from human placental microvessels. Cell Tissue Research, v. 283, p. 183-190, 1996.

KOCH, G. T.; HEERKENS, T.; THOMSEN, P. D.; BETTS, H. D. Isolation of mesenchymal stem cells from equine umbilical cord blood. BMC biotechnology, $\mathrm{v}$. 103, n. 5, p. 7-26, 2007.

KREBSBACH, P. H.; KUZNETSOV, S. A.; BIANCO, P.;GEHRON ROBEY, P. Bone Marrow Stromal Cells: Characterization and Clinical Application. Crit. Ver. Oral Biol. Méd, v. 10, n. 2, p. 165-181, 1999.

KUMAR, B. M.; JAE-GYU YOO; SUN-A OCK; JUNG-GON KIM; HYE-JIN SONG; EUN-JU KANG; SEONG-KEUN CHO; BALASUBRAMANIAN, S.; GYU-JIN RHO. In Vitro Differentiation of Mesenchymal progenitor cells derived from porcine umbilical cord blood. Molecules and cells, v. 24, n. 3, p. 343-350, 2007.

LEE, S. Y.; ANDERSON, J. W.; SCOTT, G. L.; MOSSMAN, H. W. Ultrastructure of the Placenta and Fetal Membranes of the Dog: II The Yolk Sac. The Am. J. Anatomy, v. 166, p. 313-327, 1983.

LEISSER, R; KAUFFMAN, P. Placental structure: in a comparative aspect. Exp. Clin. Endocrinology, v. 102, n. 3, p. 122-134, 1994.

LU-LU LU; YONG-JUN LIU.; SHAO-GUANG YANG.; QIN-JUN ZHAO.; XIN WANG.; WEI GONG.; ZHI-BO HAN.; ZHEN-SHU XU.; YONG-XIN LU.; DELONG LIU.; ZHIZHE CHEN.; ZHONG-CHAO HAN. Isolation and characterization of human umbilical cord mesenchymal stem cells with hematopoiesis-supportive function and other potentials. Hemat. stem cells research, v.91, n. 8, p. 1017-1026, 2006.

MANKANI, M. H.; KUZNETSOV, S. A.; SHANNON, B.; NALLA, R. O. R.; YIXIAN, Q.; ROBEY, P. G. Canine cranial reconstruction using autologous bone marrow stromal cells. Stem cells, tissue engineering and hematopoietic elements. Am. J. of

Pathology, v. 168, n. 2, p. 542-550, 2006. 
MURAGLIA, A.; CORSI, A.; RIMINUCCI, M.; MASTROGIACOMO, M.; CANCEDDA, R.; BIANCO, P.; QUARTO, R. Formation of a chondro-osseous rudiment in micromass cultures of human bone-marrow stromal cells. J. Cell Sci, v. 116, p. 2949-2955, 2003.

NAKAGE, A. P. M.; SANTANA, A. E.; CÁPUA, M. L. B.; COELHO, P. S. Metodologia e aplicação da citometria de fluxo na hematologia veterinária, revisão bibliográfica.

Ciência rural, Santa Maria, v. 35, n. 4, p. 966-973, 2005.

NAKAGE, A. P. M.; SANTANA, A. E.; Células-tronco hematopoéticas em cães.

Ciência Rural, Santa Maria, v. 36, n. 1, p. 325-329, 2006.

NEUNER, E.; SCHUMM, M.; SCHNEIDER, E. M.; GUENTHER, W.; KREMMER, E.; VOGL, C.; BUTTNER, M.; THIERFELDER, S.; KOLB, H. J. Studies on canine bone marrow long-term culture: effect of stem cell factor. Veterinary Immunology and Immunopathology, v. 61 p. 1-16, 1998.

PARK. K.; YONG-SOON LEE.; KYUNG-SUN KANG.; In vitro neuronal and osteogenic differentiation of mesenchymal stem cells from human umbilical cord blood. J. Vet Sci, v. 7, n. 4, p. 343-348, 2006

PASSEGUÉ, E.; JAMIESON C. H. M.; AILLES, L. E.; WEISSMAN, I. L. Normal and Leukemic hematopoiesis: Are leukemias a stem cell disorder or a reacquisition of stem cell characteristics? PNAS, v. 100, p. 11842-11849, 2003.

PERES, C. M.; CURI, R. Como cultivar células. Rio de Janeiro: Guanabara Koogan. p. 256, 2005.

PLOEMACHER, R. E.; VAN DER SLUIJS, J. P.; VOEMAN, J. S. A. An In vitro limiting-dilution assay of long-termrepopulating hematopoetic stem cells in the mouse. Blood, v. 74, p. 2755-63, 1989.

RUBSTEIN, P.; DOBRILA, L.; ROSENFIELD, R. E.; ADAMSON, J. W.; MIGLIACCIO, G.; MIGLIACCIO, A. R.; TAYLOR, P. E.; STEVENS, C. E. Processing and criopreservation of placental/umbilical cord blood for unrelated bone marrow reconstituation. Proc. Natl. Acad. Sci, v. 92, p. 10119-10122, 1995.

SCOTT, F. G. Developmental biology. 3 ed. USA. Sinauer Associates, 1991. cap. 4, p. 115-153, 1991. 
SUDO, K.; KANNO, M; MIHARADA, K.; OGAWA, S.; HIROYAMA,T.: SAIJO, K.; NAKAMURA ,Y. Mesenchymal progenitors able to differentiate into osteogenic, chondrogenic, and/or adipogenic cells in vitro are present in most primary fibroblastlike cells populations. Stem Cells. 2007. Disponível em <www.StemCells.com > at Royal Perth Hospital. Acesso em 13 de dezembro de 2007.

SUTHERLAND, H. J.; EAVES, C. J.; FRESHNEY, R. I.; PRAGNELL, I. B.; FRESHNEY, M. G. Long term culture of human myeloid cells. Culture of hematopoetic cells. New York: Willey-Liss, 1994. p. 139-162.

TORRENTE, Y.; BELLICHI, M.; SAMPAOLESI, M.; MEREGALLI, M.; D'ANTONA, G.; TONLORENZI, R.; PORRETTI,L.; GAVINA, M.; MAMCHAOUI, K.; PELLEGRINO, M. A.; FURLING, D.; MOULY, V.; BUTLER. Human circulating AC $133(+)$ stem cells restore dystrophin expression and ameliorate function in dystrophic skeletal muscle. J. Clin. Invest. v. 114, n. 2, p. 182-195, 2004.

TSE, W.; LAUGHLIN, M. J. Umbilical cord blood transplantation: A new alternative option. Hemat. stem cell transpl, p. 377-383, 2005.

ULLOA-MONTOYA, F.; VERFAILLIE, C. M.; WEI-SHOU, HU.; Culture System for Pluripotent Stem Cells. J. Bioscience and Bioengineering, v. 100, n.1, p 12-27, 2005.

WEISSMAN, I. L.; Stem Cells: Units of Development, Units of Regeneration, and units in Evolution. Cell, v. 100, p. 157-168, 2000.

YOUNG, H. E.; STEELE, T. A.; BRAY R. A.; HUDSON, J.; FLOYD, J. A.; HAWKINS, K.; THOMAS, K.; AUSTIN, T.; EDWARDS, C.; CUZZOURT J.; DUENZL, M.; LUCAS, P. A.; BLACK JR, A. C. Human Reserve Pluripotent Mesenchymal Stem Cells Are Present in the Connective Tissues of Skeletal Muscle and Dermis Derived From Fetal, Adult and Geriatric Donors. The Anatomical Record, v. 264, p. 51-62, 2001.

YU-JEN CHANG; SHIH CHANG; TZU-BI SHIH, D.; CHING-PING TSENG; TZU-BOU HSIEH; DON-CHING LEE; SHIW-MIN HWANG. Disparate Mesenchyme-Lineage Tendencies in Mesenchymal Stem Cells from Human Bone Marrow and Umbilical Cord Blood. Stem cells, v. 24 p. 679-685, 2006.

ZHE CHEN; ZHONG-CHAO HAN. Isolation and characterization of human umbilical cord mesenchymal stem cells with hematopoiesis-supportive function and other potentials. Hematopoietic stem cells Research, v. 91 n. 8, p.1017-1026, 2006. 